\title{
East versus West in the Iconography of Roman Mosaics: Selected Examples of Shared Themes
}

\section{Roma Mozaiklerinin İkonografisinde Doğu Batı'ya Karşı: Ortak Konulardan Seçilmiş Örnekler}

David PARRISH*

(Received 28 November 2016, accepted after revision 11 July 2017)

\begin{abstract}
This article deals with a few different artistic themes represented by mosaicists in both the eastern and western halves of the Roman empire. The themes I discuss are the Triumph of Dionysos and the subject of the hunt, both of which were popular primarily for decorating the main reception room of private homes. Dionysos's triumph evokes worldly happiness and prosperity, and the hunt, of either realistic or mythological type, reflects a popular aristocratic pastime as well as the manly quality of courage in the face of danger, or virtus. In general, the direction of artistic influence flowed from west to east, but in at least one instance, the trend in imagery moved in the opposite direction. It is shown how eastern and western craftsmen developed regional preferences in the ways they depicted the shared themes, partly shaped by local historical and economic circumstances.
\end{abstract}

Keywords: Dionysos, triumph, hunt, virtus, Meleager.

\section{Öz}

Bu makale, Roma Imparatorluğu'nun doğu ve batı yarısında mozaik sanatçıları tarafindan yansıtılan birkaç sanatsal konu ile ilgilenmektedir. Benim burada ele aldığım öncelikli olarak özel konutların ana giriş odalartnın dekorasyonu için yaygın olan Dionysos'un zaferi ve av konularıdır. Dionysos'un zaferi, dünyevi mutluluğu ve refahı anımsatmaktadır. Gerçekçi ya da mitolojik yöntemlerden birine sahip avlama ise yaygın aristokratik eğlencenin yanında, virtus ya da tehlikenin yüzündeki cesaretin erkeğe özgü niteliklerini de yansıtmaktadır. Genel olarak, sanatsal etkinin yönü batıdan doğuya doğru ilerlemektedir. Fakat, en az bir durumda imgelerdeki akım zıt yönde etkilenmiştir. Doğu ve batı zanaatkârlarının, yerel tarihi ve ekonomik durumlar tarafından kısmen şekillenen ortaklaşa konuları resmettiği biçimde, bölgesel tercihlerin nasıl geliştiği gösterilmektedir.

Anahtar Sözcükler: Dionysos, zafer, av, virtus, Meleager.

Numerous iconographic themes were represented by mosaicists in both the eastern and western halves of the empire over a period of several centuries**. Some subjects were transmitted from west to east with relatively few changes in the content of the imagery, whereas other themes underwent significant adaptation. One means of transmission was model books which circulated among workshops but are now lost. In other instances, itinerant craftsmen brought their knowledge with them when they traveled abroad to execute commissions.

\section{The Triumph of Dionysos}

The first of two themes I wish to consider in this article is the Triumph of Dionysos, a mythological subject of great popularity for decorating primarily private homes in both regions of the empire, specifically, a building's triclinium

\footnotetext{
* David Parrish, School of Visual and Performing Arts, Purdue University, West Lafayette, Indiana, USA. E-mail: dparrish@purdue.edu

** I wish to thank Maria de Jesus Kremer for her kind invitation to participate in the $1^{\text {st }}$ International Meeting of RoGeMoPorTur in Alter do Chão, with its theme of East meets West. The colloquium was a model of superb organization and generous hospitality.
} 


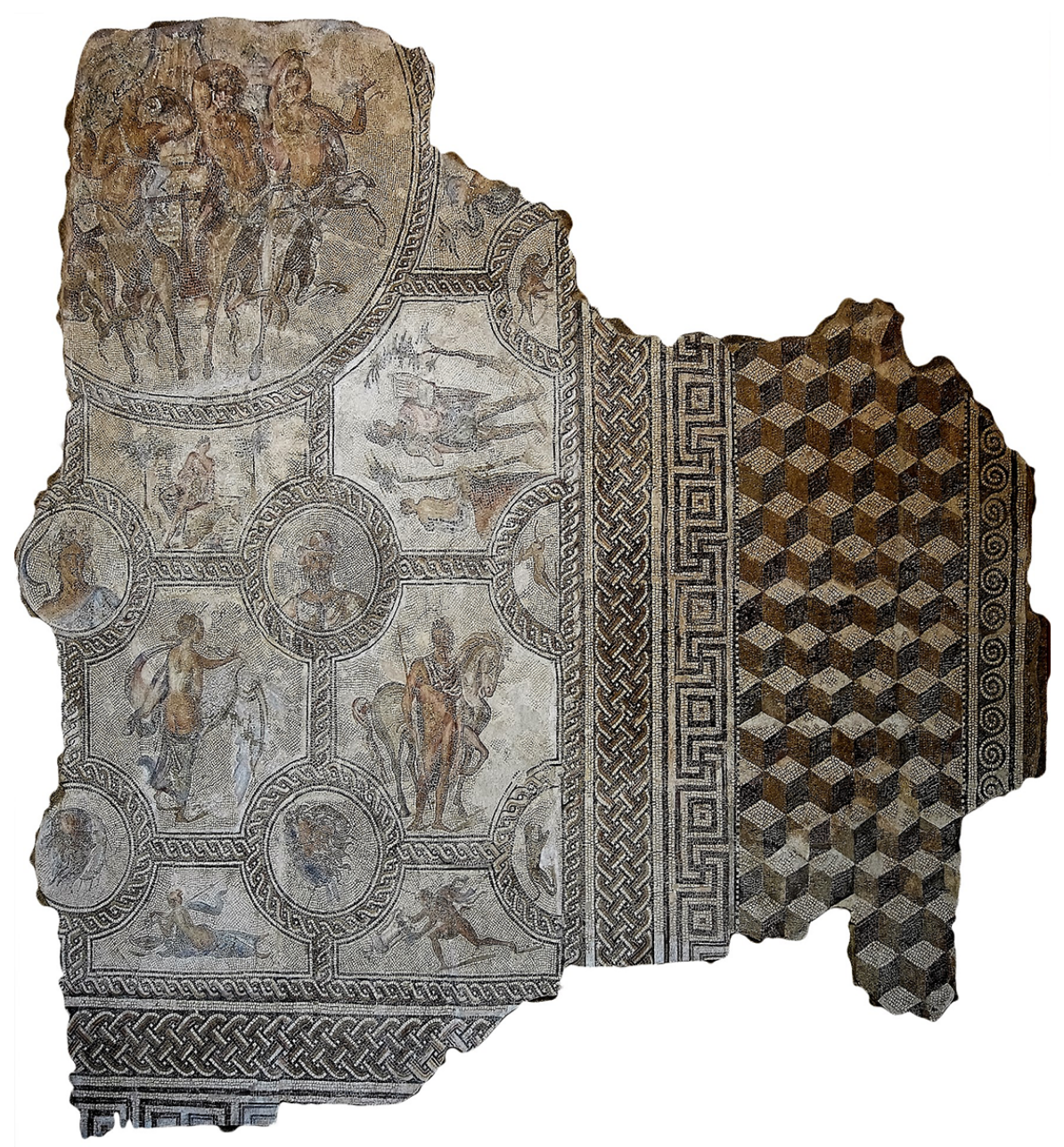

Figure 1

Écija, Mosaic with Triumph of Dionysos. Écija, Museo Histórica Municipal. Photo courtesy of Sebastian Vargas Vázquez

or main reception room. At least one other example occurs in a public bath building. Other scholars have analyzed this subject's representation in mosaics ${ }^{1}$, and I shall try to clarify the east-west relationship in the imagery, being very selective about the examples discussed. The theme of the wine god's triumphant return from his conquest of India began appearing in Roman mosaics in the $2^{\text {nd }}$ century $\mathrm{CE}$, and it experienced a gradual development, influenced in part by Roman imperial art. In early representations, Dionysos stands alone or with a mythical companion in a centaur-driven chariot, which passes over the land or sea. The entire group occupies a single panel, often placed within a larger pavement that includes other mythological and allegorical individuals. This iconography first appeared in the western empire in both North Africa and Spain and then spread eastward to the Greek world. An early example is found in a large mosaic that decorated the Baths of Trajan at Acholla (Picard 1948: 810-815 fig. 1; Yacoub 1995: 30-33 fig. 5a, 5b) in Tunisia. It shows the chariot group of Dionysos, who holds a wine vessel, and a pair of centaurs in a panel surrounded by a procession of sea-creatures; busts of the seasons also punctuated the design. The god is understood as a cosmocratic figure having universal powers of fertility.

Two Spanish mosaics of the second half of the $2^{\text {nd }}$ century retain the format of a centralized panel with the triumphant Dionysos. In one case, a pavement from Alcolea (Garcia y Bellido 1965: 2-6 fig. 2-13; Tarradell 1969: 95, 97, 230-231

1 See, e.g., Dunbabin 1971; Fernández-Galiano 1984; Kondoleon 1994: 191-229; López Monteagudo 1998: 191-222; Yacoub 1995: 48-54. 
no. 73 fig. on 95; López Monteagudo 1998: 191, 200-202), members of the thiasos are shown standing in separate panels around the victorious deity, while heads of wind gods occur in the mosaic's corners. The overall arrangement suggests a Dionysiac procession on land, and the deity's power to bring prosperity is symbolized by large ivy leaves and grape leaves placed in the composition's intervals. The cosmic importance of Dionysos is expressed differently in a fragmentary mosaic from Écija (López Monteagudo 1998: 191-194 pl. 1,1, 1,2; Vargas Vázquez 2014: 25-26 pl. 5), in which Dionysos and his chariot appear in frontal view in a large central medallion, and the god wears a long robe; his wagon is pulled by two pairs of centaurs like a quadriga (Fig. 1). Season busts occupy flanking panels, as do Dionysiac masks, and various mythological figures fill other compartments. It is an elaborate scheme focused on the triumphator.

When eastern mosaicists of the $2^{\text {nd }}$ century began illustrating the Triumph of Dionysos, they too showed Dionysos and his centaur-guided chariot in frontal view, and they initially preferred to represent these figures in a marine setting. A satyr now accompanies the god in his chariot. In a pavement from Corinth (Weinberg 1960: 114, 117-118 pl. 54, 57,1), it is a pair of sea-panthers that pulls the wagon flanked by centaurs (there also are single Erotes in adjacent panels), whereas a mosaic from Dion (Pandermalis 1997: 56-59, col. photos on $56-57,59)$ substitutes hippocamps for panthers. The half-nude Dionysos in the latter pavement holds a rhyton in one hand and a thyrsos in the other hand, as Silenos, wearing a woolen chiton, rides in the chariot beside him. The overall presentation in the Dion mosaic recalls African mosaics depicting the Triumph of Neptune, such as a pavement of Antonine date from La Chebba (Parrish 1984: 201-204 pl. 66b-68; Blanchard-Lemée et al. 1995: 49, 134 fig. 22a-b, 23-24, 90-91; Yacoub 1995: 149-151 fig. 70a-d), discussed in this context by G. López Monteagudo.

A key change in the iconography of Dionysos's Triumph in Roman mosaics occurred in the late $2^{\text {nd }}$ century to early $3^{\text {rd }}$ century, when this subject usually appeared in an expanded format, presenting a procession on land with new types of figures participating. This development clearly shows the influence of sarcophagi of Dionysiac content produced in Rome, as has been previously demonstrated. Of the many Dionysiac sarcophagi inventoried by F. Matz, one of the most impressive is an example kept in the Walters Art Museum in Baltimore (Matz 1968: 231-233 no. 95 pl. 116-120), and dated by the author to the years 170-180 CE (Fig. 2). The frieze with the Triumph of Dionysos is a riotous, rightwardmoving procession that shows the god standing in a chariot at the left end, fully draped in a long robe and with a laurel crown and thyrsos; he is accompanied by Victory, in imitation of Roman imperial triumphs. The wagon is pulled by a pair of panthers led by a satyr, and other satyrs and maenads, as well as Silenos and a few more felines join the throng. One maenad gaily strikes a tympanon. Also present are exotic animals, elephants and a camel, and one of the former bears a bound Indian captive.

This enriched iconography had a direct impact on mosaics in the west, especially in North Africa and Spain, and also spread eastward with regional adaptations. A fine African example is a pavement from Sousse (Yacoub 1995: 49 fig. 13) in Tunisia dated to the beginning of the $3^{\text {rd }}$ century, in which Dionysos, fully draped and with a crown of bunches of grapes, stands in a chariot drawn by four tigers, as Victory stands beside him holding a palm branch (Fig. 3). Leading the chariot is a satyr, now partly missing, and a dancing maenad strikes a tambourine; a vase-carrying satyr and additional felines also are visible. Surrounding the tableau is a lush grapevine with vintaging Erotes, emphasizing the notion of 


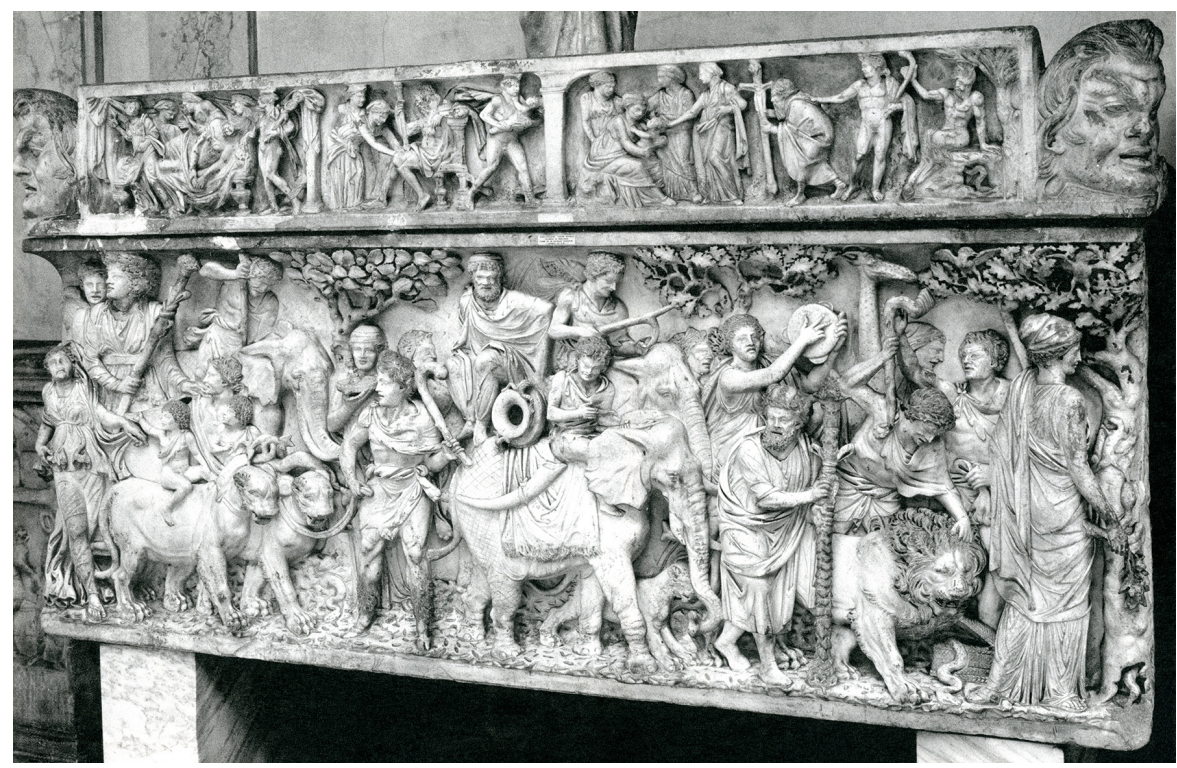

Figure 2

Rome, Sarcophagus with Triumph of Dionysos. Baltimore, Walters Art Museum.

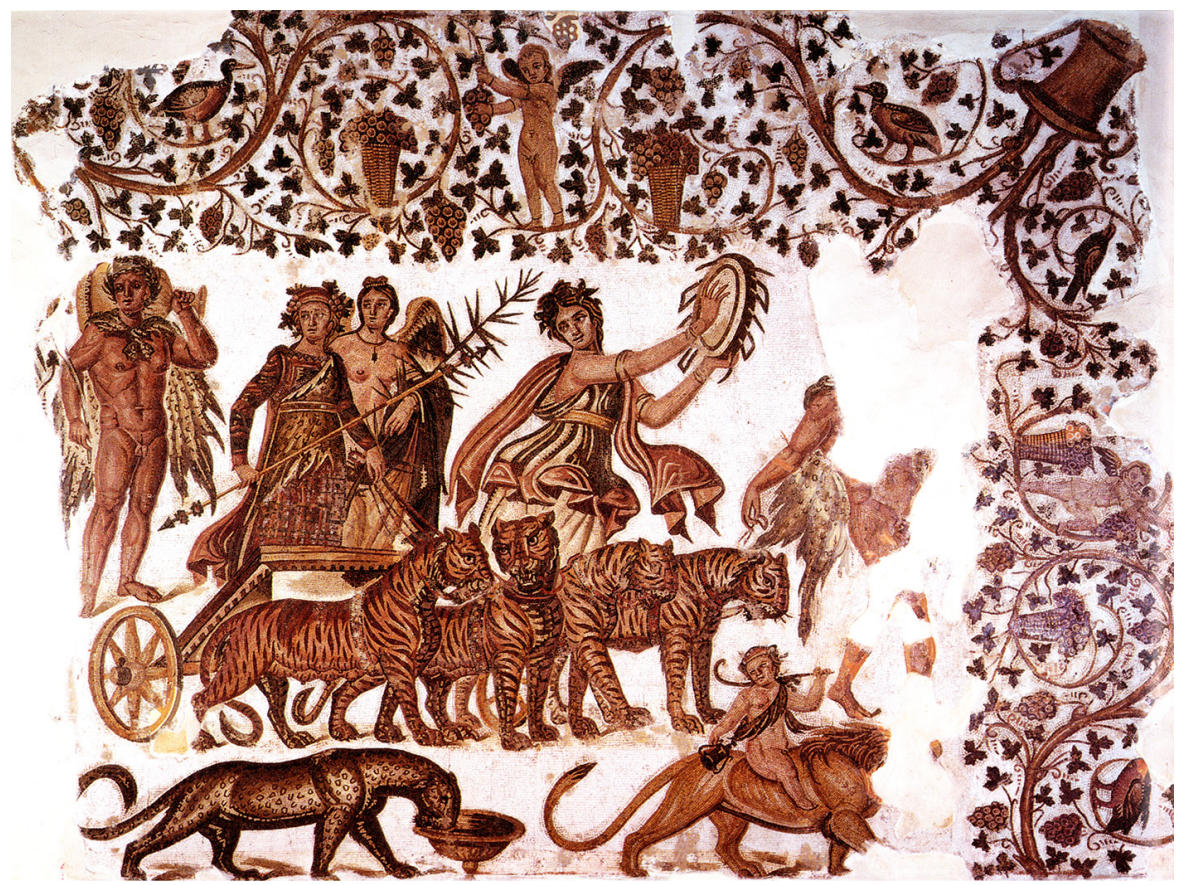

Figure 3

Sousse, Maison du Virgile, Mosaic with Triumph of Dionysos. Tunis, Musée du Bardo.

worldly abundance brought by the god. Another African mosaic of late $3^{\text {rd }}$-century date from Sétif (Blanchard-Lemée 2005: 294-299 fig. 4-8) in Algeria echoes the Baltimore sarcophagus more fully (Fig. 4). Dionysos and Victory appear at the left end in a chariot drawn by tigers, in this case led by Pan. Further ahead in the cortège appear not only an elephant, but also two bound captives riding on the back of a camel as other, royal prisoners walk alongside. Silenos, fully draped and with a tall staff, precedes this group. A lush acanthus border with inhabited scrolls, appearing on a dark ground, frames the entire scene ${ }^{2}$.

Eastern mosaicists adopted these innovations for representing Dionysos's triumph in varying degrees, adding original features of their own. An abbreviated

2 Stylistically, the Sétif mosaic seems related to Syrian pavements, specifically, in the treatment of the acanthus border, showing inhabited scrolls against a black ground; see W. Daszewski's remarks about the Sétif mosaic, Blanchard-Lemée 2005: 301. Although eastern craftsmen may have influenced, or even executed, the Sétif floor, the iconography of the Dionysiac procession is purely western in origin. 


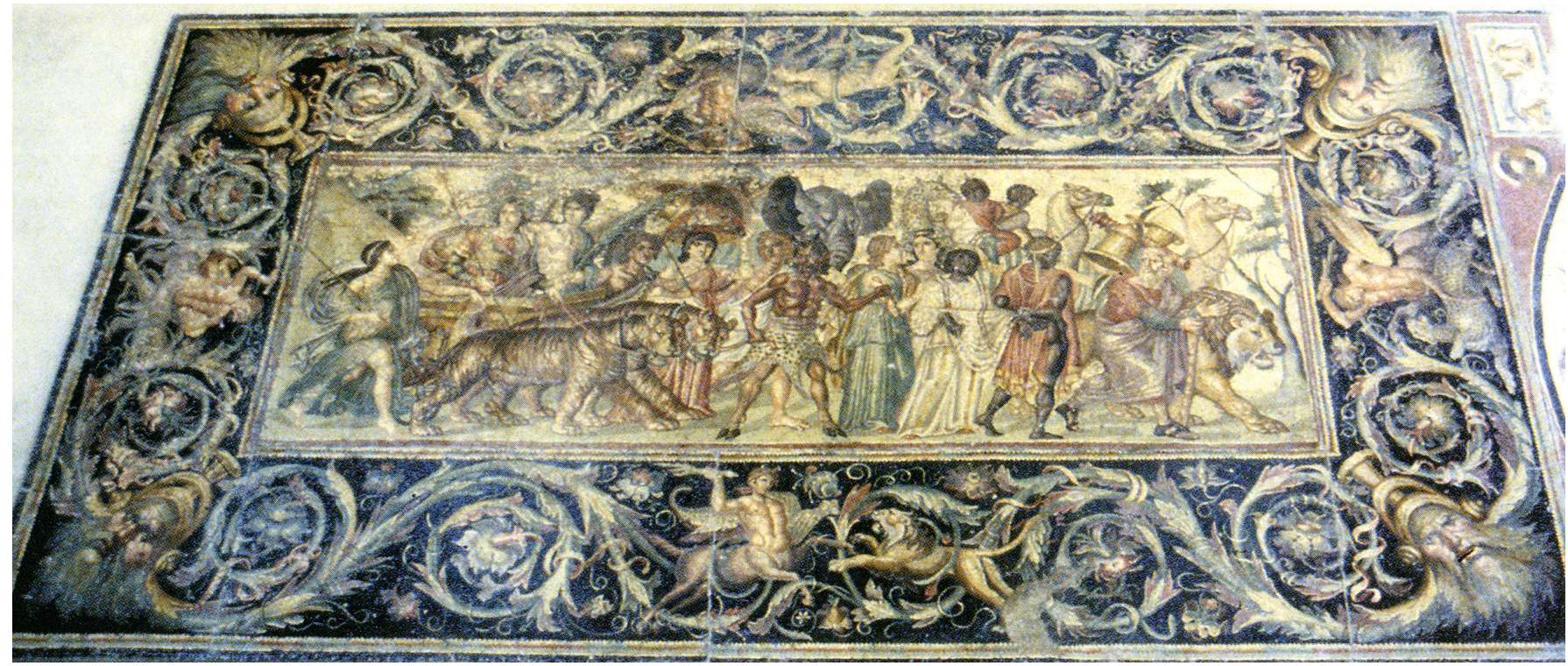

Figure 4

Sétif, Mosaic with Triumph of Dionysos. Djemila, Musée archéologique.

Figure 5

Zeugma, Mosaic with Triumph of Dionysos. Gaziantep,

Archaeological Museum.

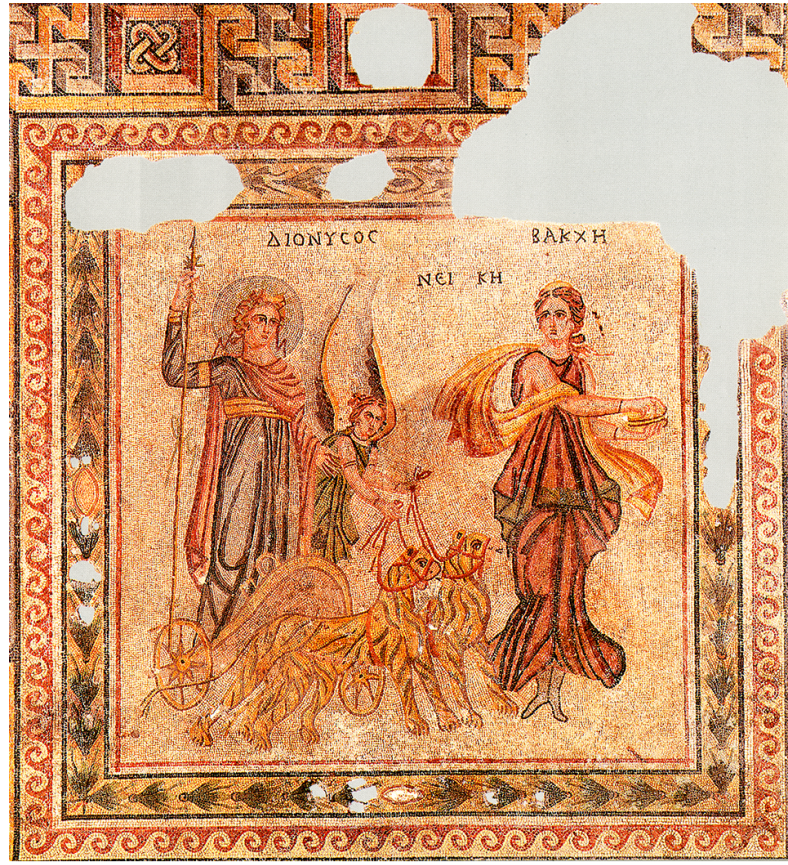

version of western models is observed in a pavement of the late $2^{\text {nd }}$ to early $3^{\text {rd }}$ century from Zeugma (Önal 2002: 18-21 fig. on 19; Abadie-Reynal - Ergeç 2012: 240-241 fig. 271-272 (upper part); 260-261 (Tapis 4, Tableau 1) fig. $297-$ 299 pl. 47) (Fig. 5). It is almost like a quotation of the central part of the pavement from Sousse (Fig. 3), but with figures' names inscribed in Greek. In the Turkish floor, Dionysos, nimbed, richly draped in a long belted tunic and cloak, and holding a thyrsos, stands in a chariot pulled by a pair of tigers, as Nike rides alongside. Here, however, instead of crowning the god, Nike grasps the reins of the wagon, and a maenad labeled Bacche dances in front.

Other eastern mosaicists excluded Nike from the triumphal chariot and showed the wine god centrally placed in a procession, with members of his entourage spread out to either side. This can be seen in a pavement from the House of Dionysos at Paphos (Kondoleon 1994: 191-205 fig. 119-120, 126-127, front of book's dustcover), published by C. Kondoleon and also referred to by G. López 

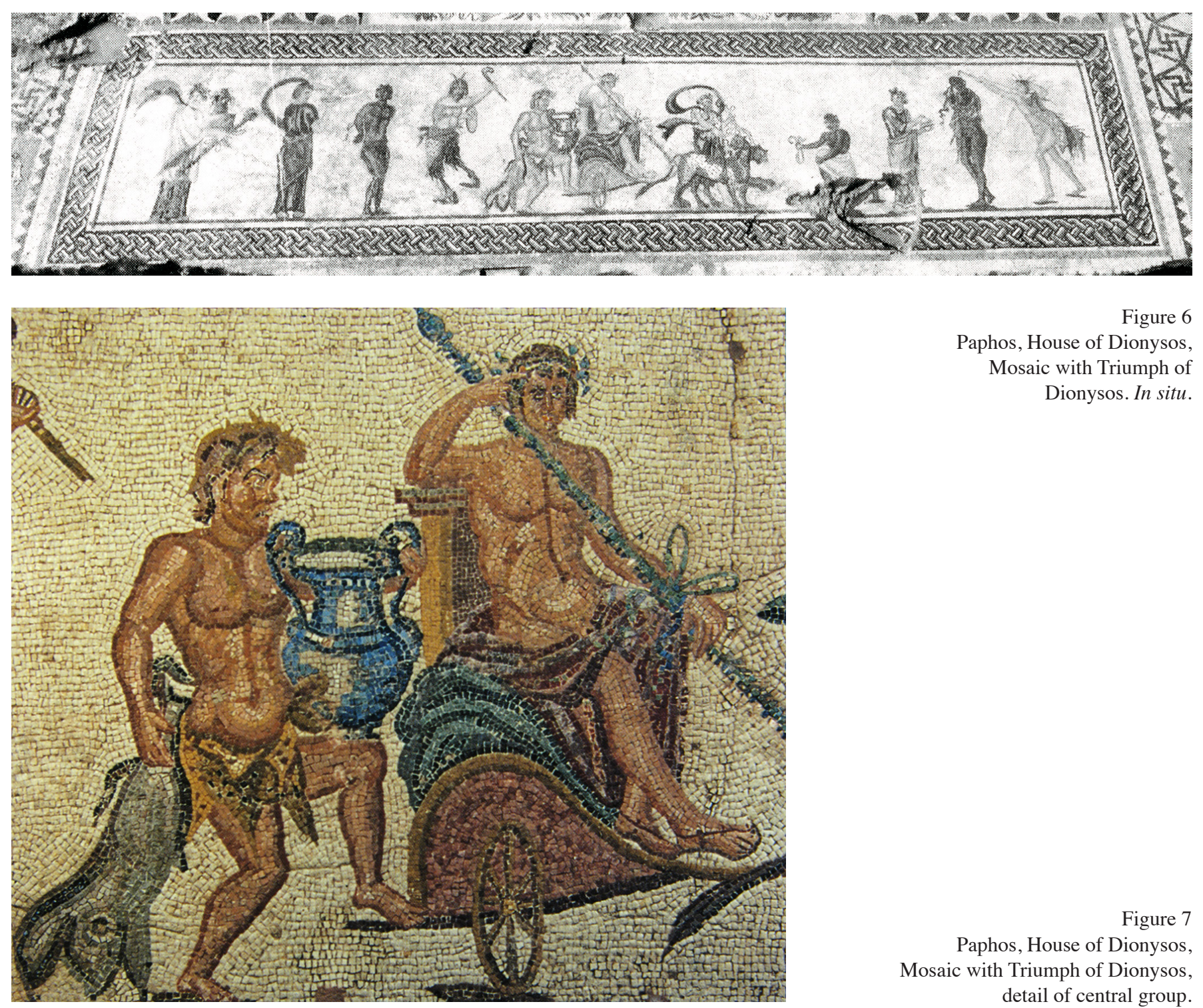

Figure 6

Paphos, House of Dionysos, Mosaic with Triumph of Dionysos. In situ.

Monteagudo (Fig. 6). In a symmetrical arrangement, Dionysos, seen in threequarter view, sits in his chariot pulled by a pair of leopards and guided by Silenos (who wears a woolen garment), as a satyr with a wine crater tries to enter the vehicle (Fig. 7, detail of the central group). The god is framed by standing satyrs and maenads, in addition to Pan and two bound Indian captives, placed at regular intervals on either side of the chariot. The design appears static rather than moving forward. A horizontal frieze with Dionysos in the middle also occurs in a contemporary mosaic from Antioch (Levi 1947: 93-99, fig. 36-38, pl. XV,c; Cimok 1995: 36-37, fig. on these pages), of which only the center and left half are preserved (Fig. 8). In this case, Dionysos's chariot is seen from the front, as members of the thiasos, including Pan, appear on the left. We finally mention a fragmentary mosaic from Sepphoris (Talgam - Weiss 2004: 63-66 fig. 48 col. pl. I,A), of which only the first part of the triumphal procession, inscribed Pompe, remains. Here nimbed Dionysos reclines in a chariot pulled by music-playing centaurs, a pose also adopted by the god on some sarcophagi ${ }^{3}$, and the procession moves leftward.

3 Cf. sarcophagi from the Villa Doria Pamphili and the Villa Savoia in Rome, Matz 1968: 279-280, no. 142 , pl. 170,1 ; no. 146 , pl. 171,2 ; no. 148 , pl. 168,1 . 
Figure 8

Antioch, Mosaic with Triumph of Dionysos, center and left half. Antakya, Archaeological Museum.
In the late antique period of the $4^{\text {th }}$ and $5^{\text {th }}$ centuries, the regional distinctions between eastern and western representations of Dionysos's Triumph become more pronounced. In the west, the previous iconographic developments persist in colorful fashion, as for example, in an early $4^{\text {th }}$-century mosaic from Torre de Palma (Guardia Pons 1992: 267-270 fig. 118; Lancha - André 2000: 175-179 pls. LXV-LXXII, a), showing a crowded procession of the god's followers, including Pan and a maenad sounding small round cymbals, customary objects of the thiasos; Dionysos rides in his chariot on the left accompanied by a satyr. The imagery conveys the uninhibited joy of the celebrants without making specific allusions to religious practice. A much more condensed version of the triumph appears in a $5^{\text {th }}$-century pavement from Baños de Valdearados ${ }^{4}$, displaying the nude Dionysos and a satyr riding in a chariot drawn by two panthers, as a maenad holding a flabellum stands alongside. The naïve, provincial style of the mosaic, emphasizing frontal poses of the figures, is striking.

By contrast, some eastern mosaics introduced novel references to the Dionysiac mysteries, seeming to reflect the continued vitality of the pagan cult in the eastern empire. A new type of Silenos appears, for example, in a pavement at Nea Paphos (Daszewski 1985: 24-27 pl. 3-4 fig. 3, lower left corner) published by W. Daszewski (Fig. 9). We see the bearded and balding Silenos in unfamiliar dress as part of the Triumph of Dionysos, riding a donkey next to the wine god's chariot, pulled by a centaur and centauress with musical instruments (one of them holds a lyre), and preceded by a maenad with a ritualistic object. The Silenos, labeled Tropheus, meaning Dionysos's teacher or tutor and foster father, wears close-fitting trousers, shoes, and a short tunic and cloak and has a thoughtful expression like a philosopher. He is an original figure type who has artistic parallels

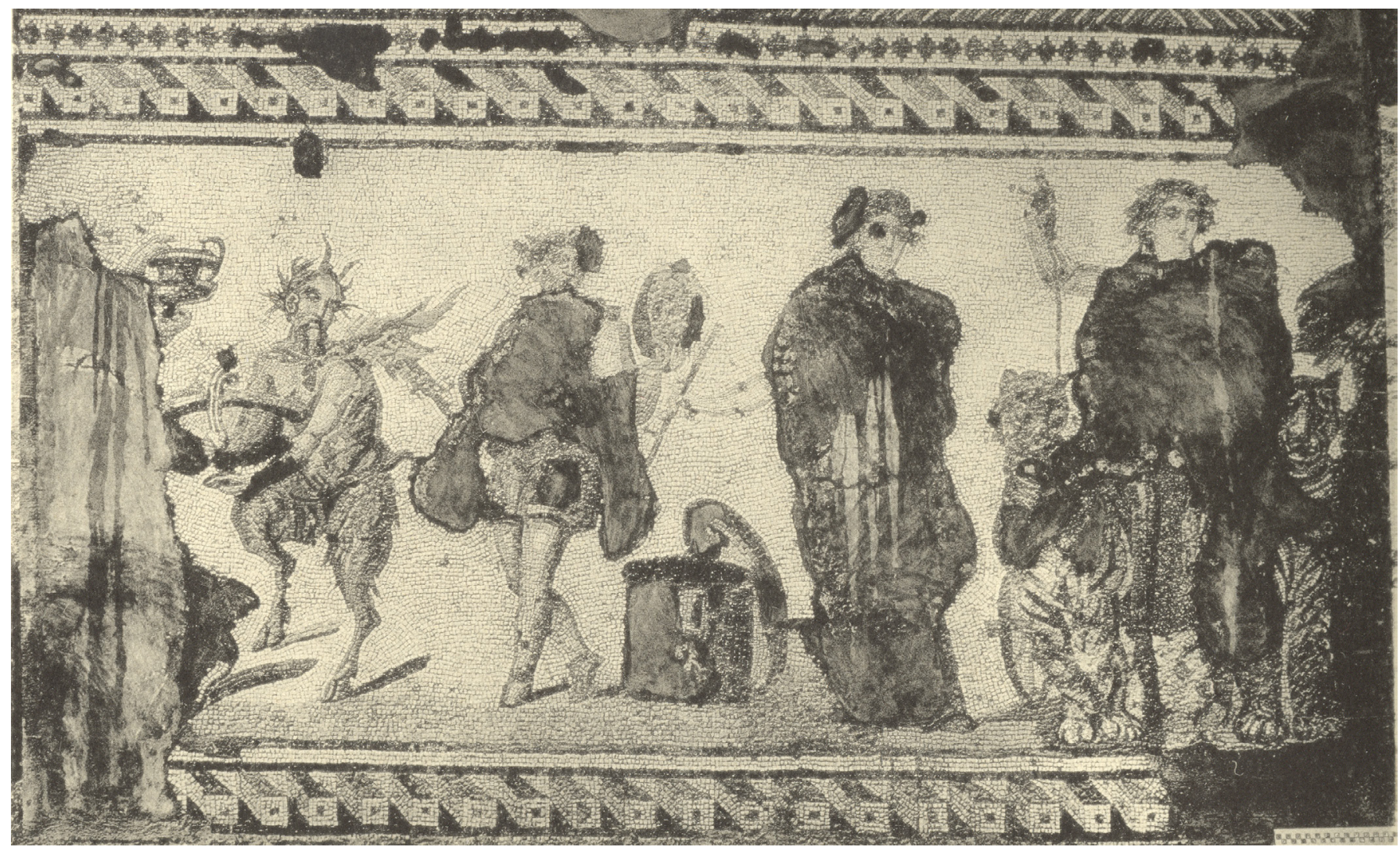

4 See Fernández-Galiano 1984: 107-108 fig. 6; Guardia Pons 1992: 121 fig. 39 (lower part), 40. 


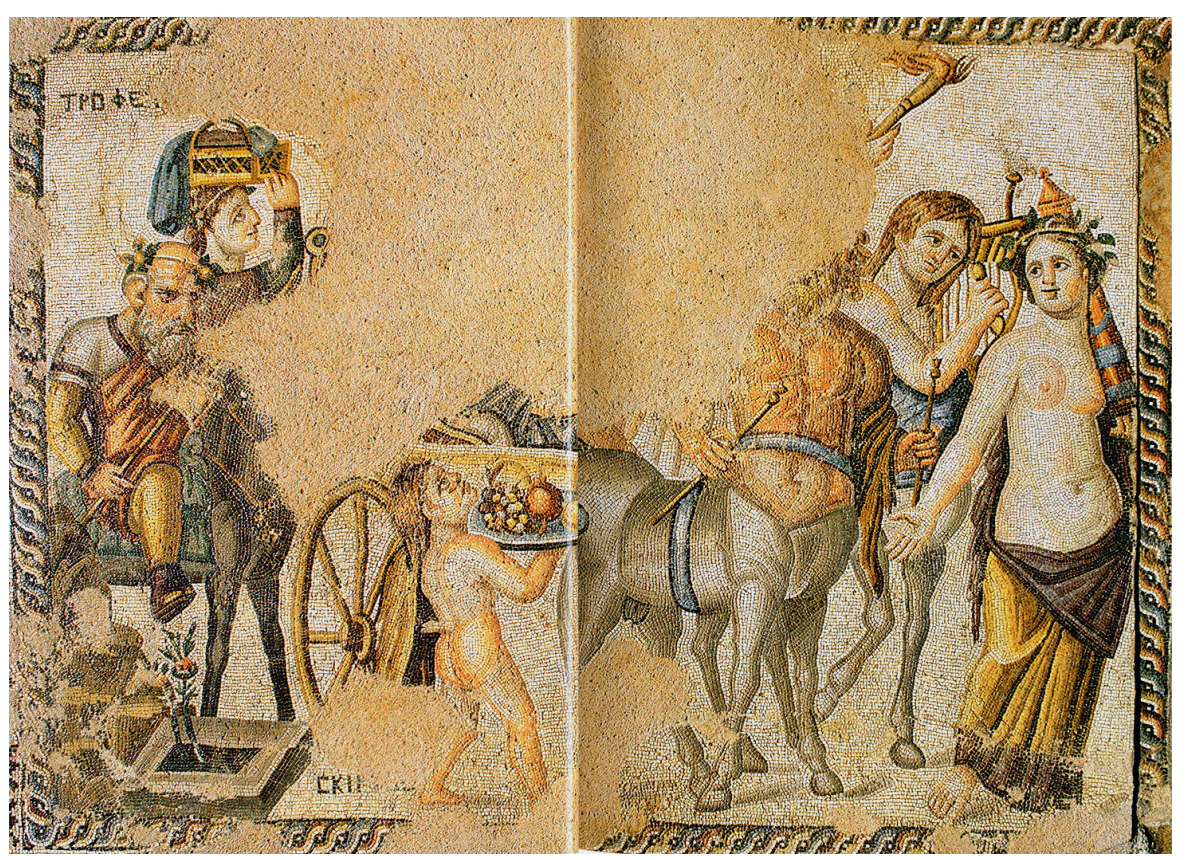

in various eastern monuments, such as a $4^{\text {th }}$-century Coptic textile ${ }^{5}$ representing members of the thiasos, including the same type of Silenos (Fig. 10). In this instance, he holds a baton or scourge with a small pouch at the end, apparently an instrument of the mysteries, and he stands framed by an arch. J. Balty identified the same sort of Silenos in a $6^{\text {th }}$-century mosaic from an aristocratic house at Sarrîn (Balty 1990: 37-44 pl. IX,3 and col pl. C,2) on the Syrian frontier, in which this individual dances with cymbals in the mysteries, alongside a nurse holding a februum (Fig. 11, one section of the mosaic). A cista mystica appears in the background.

Another late antique mosaic from the east makes a clear reference to the Dionysiac mysteries epigraphically rather than visually. It is a pavement from Sheikh-Zuweid (Ovadiah et al. 1991, 181-190 pl. 22; 23d; 24; 25a-c) in the Sinai peninsula, dated by A. Ovadiah and his colleagues to the mid- $4^{\text {th }}$ to mid $-5^{\text {th }}$ centuries, of which the latter date is the more likely (Fig. 12). In two superimposed registers, there appears a very full depiction of the Triumph of Dionysos, beginning at the left end of the upper register and continuing to the right end of the lower register. Greek inscriptions identify the participants. In the upper corner appears Dionysos fully draped and seated in a chariot drawn by a pair of centaurs with musical instruments; holding the reins is Eros. Immediately above the winged child is the word Telete (Fig. 13), a direct reference to the mysteries also found in some earlier eastern mosaics of Dionysiac content. These include mosaics from Zeugma and an unknown site, from which it passed into a private collection. As explained in a thoughtful article by K. Dunbabin, the word telete has associations both with Dionysiac initiation and the ritual of marriage ${ }^{6}$. The rest of the procession in the Sheikh-Zuweid floor includes several satyrs and maenads, as well as Pan, who shakes a pair of crotala, Silenos in traditional garb, and the drunken Herakles. The fact that the word telete appears in this late pavement may be further evidence of the mysteries' persistent practice in various regions of the eastern empire.

\footnotetext{
5 Kept in the Abegg-Stiftung, Riggisberg. See Willers 1987: 10, 21-22 fig. on far left of wall hanging, and here described as a figure in peasant dress.

6 On this point generally, see Dunbabin 2008: 217-221.
}

Figure 9

Nea Paphos, House of Aion, Mosaic with Triumph of Dionysos. In situ.

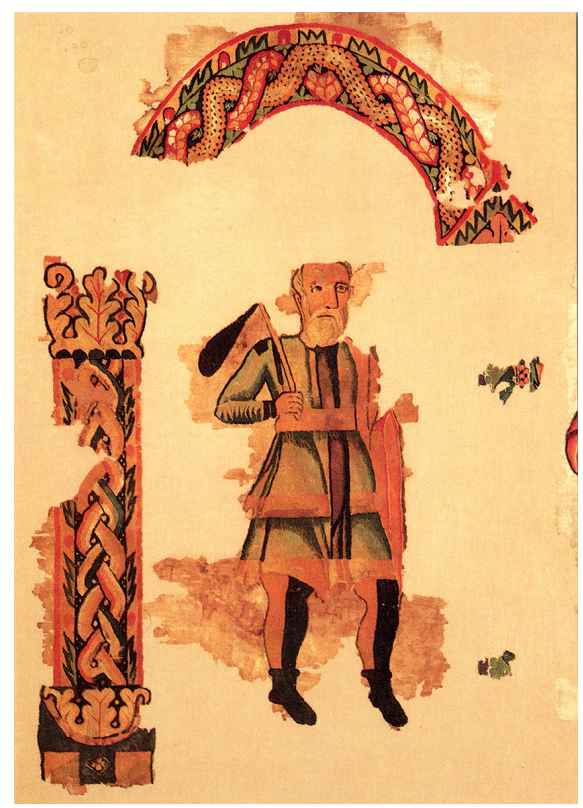

Figure 10 Coptic textile with members of thiasos, detail of Silenos. Riggisberg, Abegg Stiftung.

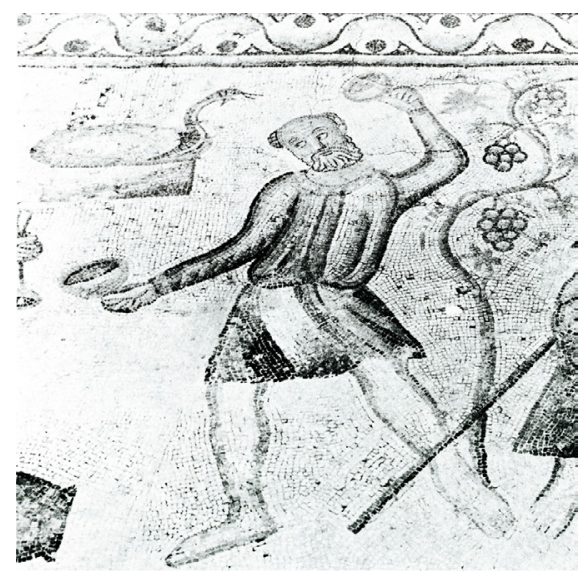

Figure 11

Sarrîn, Mosaic with Dionysiac thiasos, detail of Silenos. In situ. 


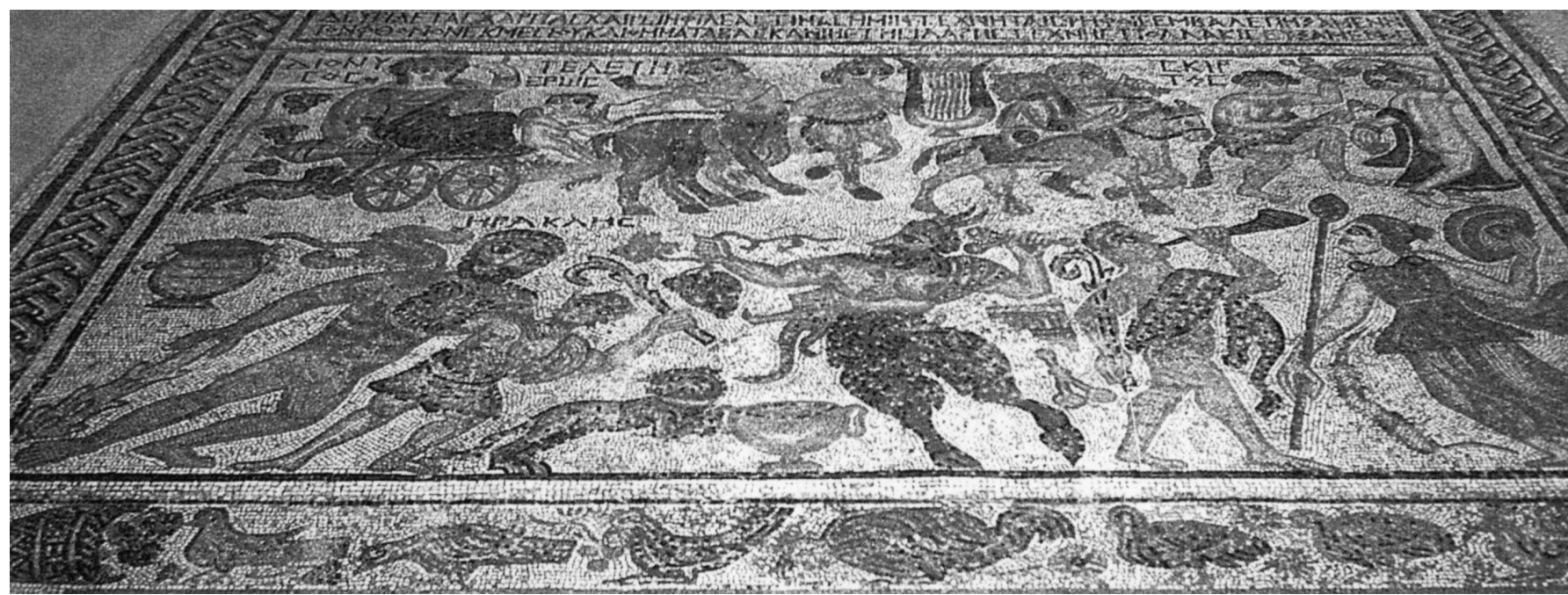

Figure 12

Sheikh-Zuweid, House of

Nestor, Mosaic with Triumph of Dionysos. In situ.

Figure 13

Sheikh-Zuweid, Mosaic with Triumph of Dionysos, detail of Dionysos and Eros.

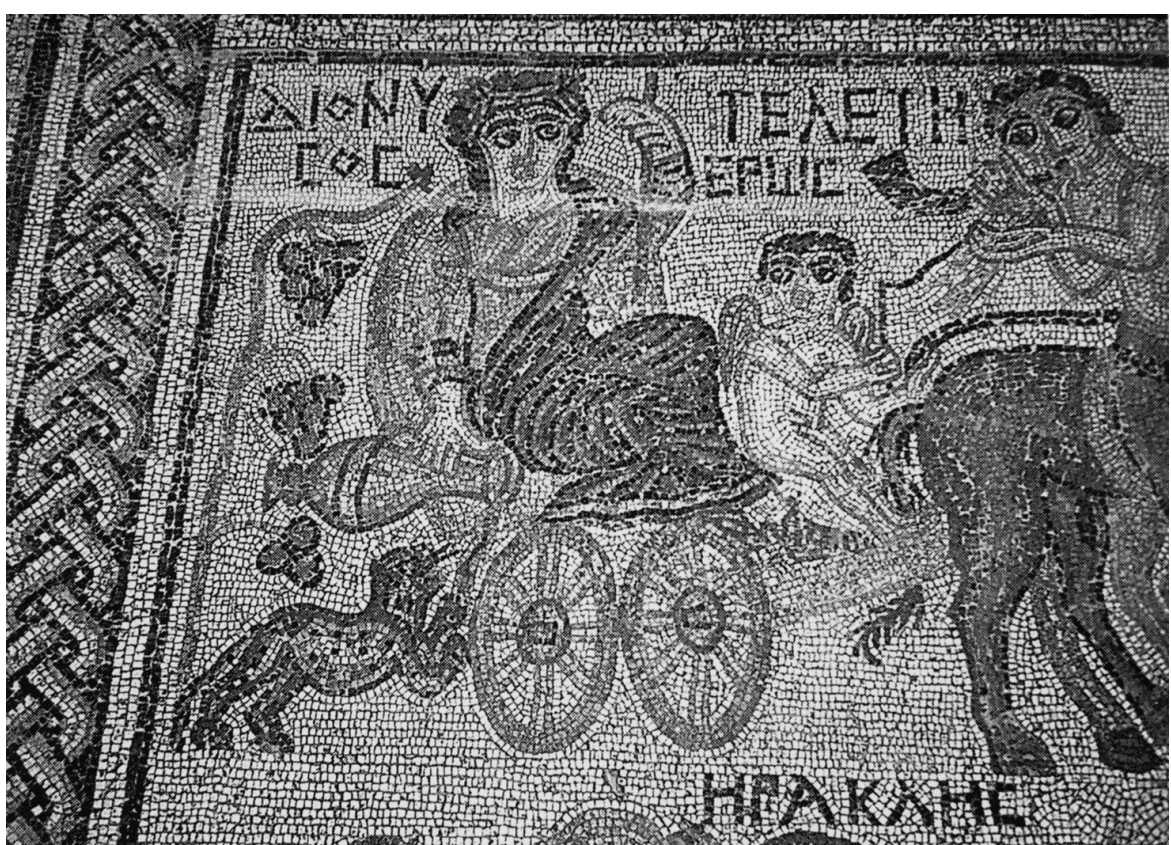

In the cosmopolitan capital of Constantinople, however, practice of the Dionysiac religion had been vanquished by Christianity in the $5^{\text {th }}$ century, although Dionysiac imagery remained popular among the educated social elite as part of their classical heritage. That includes representations of the Triumph of Dionysos, as depicted in a fragmentary mosaic from the Psamatia district of Constantinople (Dalgıç 2015), recently published by Ö. Dalgıç and dated to the second half of the $5^{\text {th }}$ century. The pavement, which ornamented a large reception room in a private house, had a circular format with a central medallion showing the god and a now missing figure (thought to be Ariadne) riding in a chariot drawn by four panthers, all seen in frontal view (Fig. 14, a reconstruction drawing by the author). Around the medallion unfolded a frieze of the thiasos, its members dancing and making music ecstatically; one observes, for example, a maenad sounding long-handled crotala. The most intriguing figure in the procession is a male flutist dressed in contemporary eastern costume of purely secular type that includes a tunic, cloak, and Phrygian cap (Fig. 15). In Dalgıç's view, the presence of this non-mythological figure in a mosaic representing Dionysos's triumph reflects human reenactment of the 
thiasos, as a type of theatrical entertainment that took place in private homes (Dalgı̧ 2015: 47).

In the early $5^{\text {th }}$ century in the west, there occurs one other striking development in mosaic imagery of the Triumph of Dionysos, namely, a reversal in the direction of artistic influence in representing this theme, now flowing from east to west. It occurs in the Dionysos panel ornamenting the triclinium of the villa at Noheda (Valero Tévar 2013: 325, 328-329 [Panel D] fig. 19) in Spain, excavated by M. A. Valero Tévar (Fig. 16, center and left half of the mosaic). In eastern fashion, there appears a large frieze of nearly symmetrical design, with Dionysos's chariot appearing in the middle in frontal view, and the thiasos extending outward in symmetrical fashion to the left and right. The design recalls earlier mosaics from Paphos (Fig. 6) and Antioch (Fig. 8). At Noheda, the chariot is pulled by two pairs of music-making centaurs. To be sure, the central group has a western antecedent at Écija (Fig. 1), but the design of the frieze as a whole seems eastern-derived. The pavement is a fusion of eastern and western artistic elements, including the identity of the riders in the chariot, respectively,

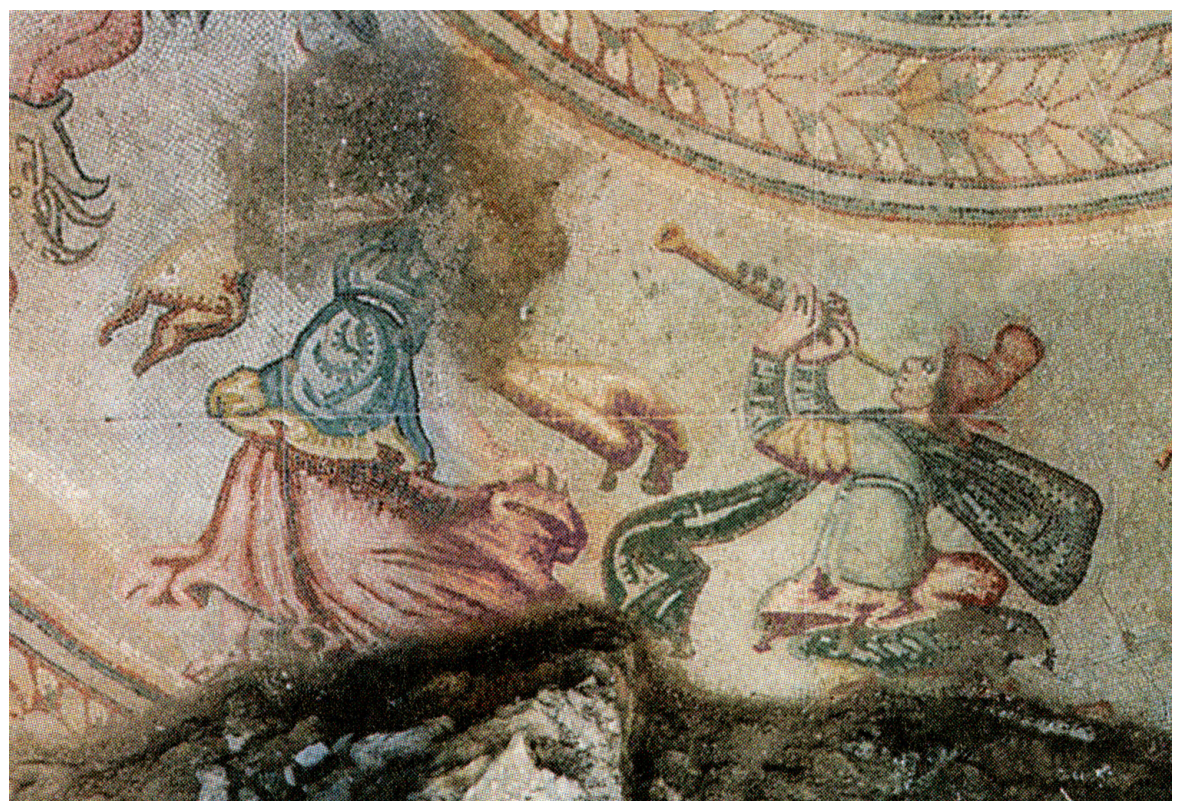

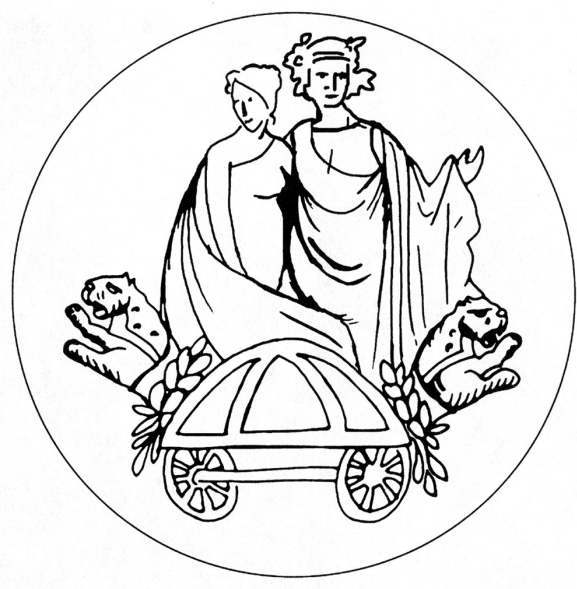

Figure 14

Constantinople, Mosaic with Dionysiac procession, reconstruction drawing of central medallion (Ö. Dalgıç). Istanbul, Archaeological Museum.

Figure 15

Constantinople,

Mosaic with Dionysiac

procession, detail of

flue player.

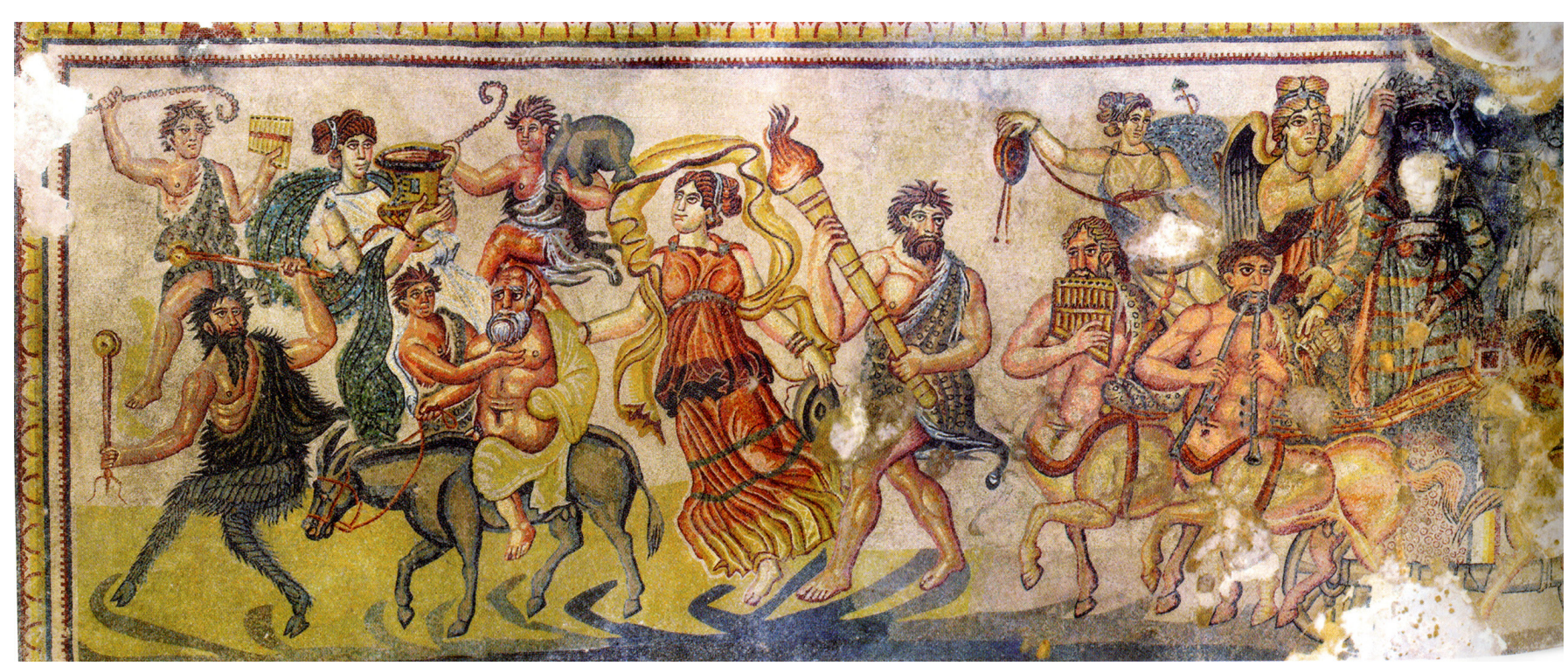

Noheda, Mosaic panel with Triumph of Dionysos, detail of center and left half, In situ. 
Victory on Dionysos's right and a damaged figure thought to be Ariadne on his left. Among the numerous merrymakers in the thiasos are torch-bearing satyrs and a sprightly Pan with long-handled crotala at the left end, who is paralleled in the pavement from Sheikh-Zuweid (Fig. 12). The Noheda mosaic blends several iconographic strands in representing the Triumph of Dionysos.

\section{The Theme of the Hunt}

We turn now to a second popular theme in mosaics of both the eastern and western halves of the empire, namely, the hunt, reflecting a favorite pastime of the aristocratic elite and exemplifying the notion of virtus. It was represented most often, like Dionysos's triumph, in the main reception room of private houses or a location nearby. This subject was first closely examined in mosaics by I. Lavin (Lavin 1963) in a groundbreaking article published in 1963. Hunting imagery of the Roman era had many antecedents in Hellenistic Greek art ${ }^{7}$, and it also was influenced by imperial Roman iconography ${ }^{8}$. Eastern and western mosaicists illustrated this subject either in a panel with a single row of figures, a composition in multiple registers, or a centralized design. The theme enjoyed special favor in the middle and later empire.

Hunting imagery in various contexts, both realistic and mythological, conveys the pleasure and exhilaration of the sport as well as the courage and cunning of the hunter. It also is sometimes associated with staged hunts in the amphitheater or venationes sponsored by the mosaic patron. The particular emphasis varies from one pavement to another. An early hunting mosaic of western origin is a $3^{\text {rd }}$-century pavement from El Jem (Yacoub 1995: 251-252 fig. 129) in Tunisia

Figure 17

El Jem, Mosaic of hare hunt. Tunis, Musée du Bardo.

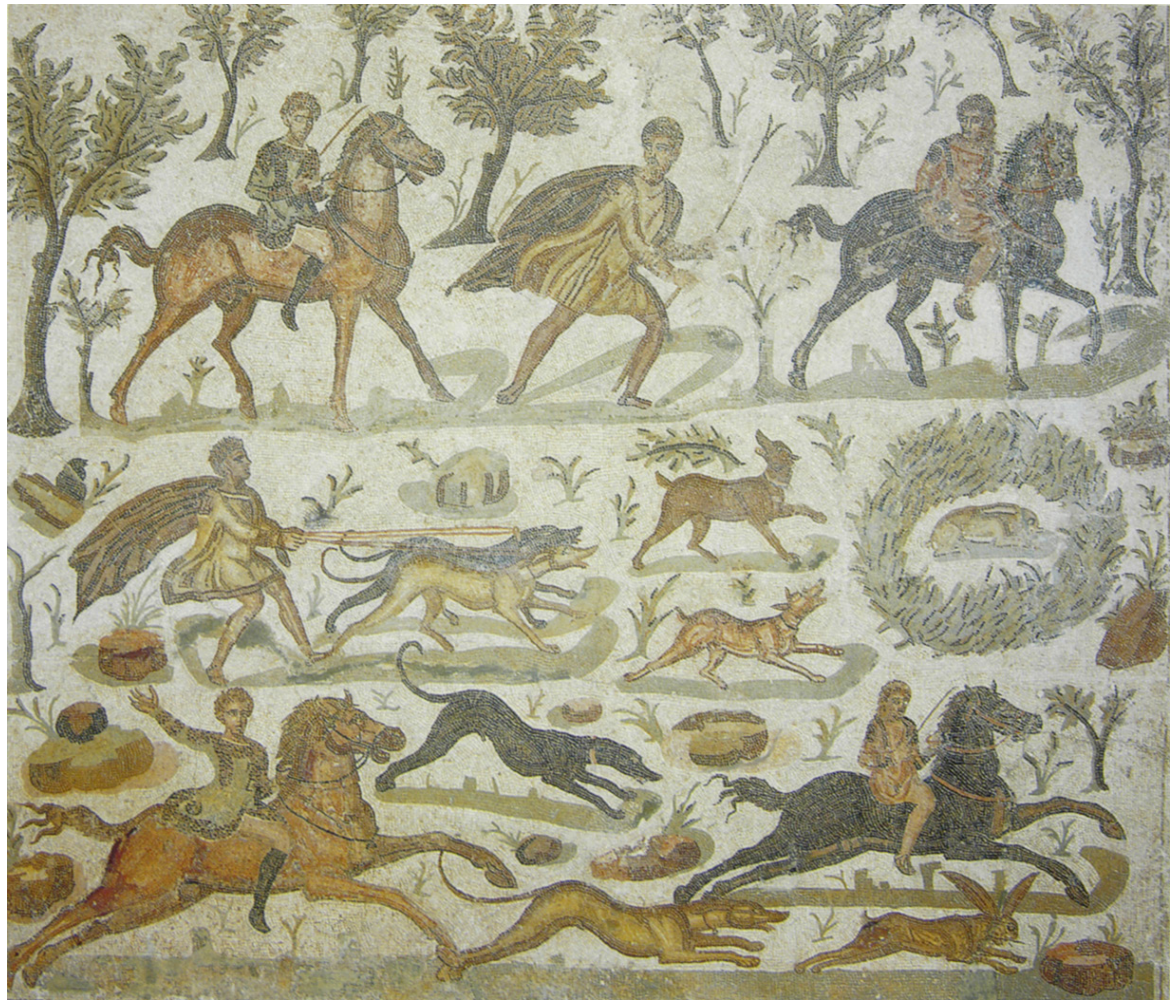

7 Cf., e.g., pebble mosaics of a Lion Hunt and a Stag Hunt from Pella, Ling 1998: 21-23 fig. 12-13, and sculpted hunting reliefs on the Alexander Sarcophagus, Ridgway 1990: 43 pl. 10, 12.

8 See, e.g., the Hadrianic hunting reliefs on the Arch of Constantine. 


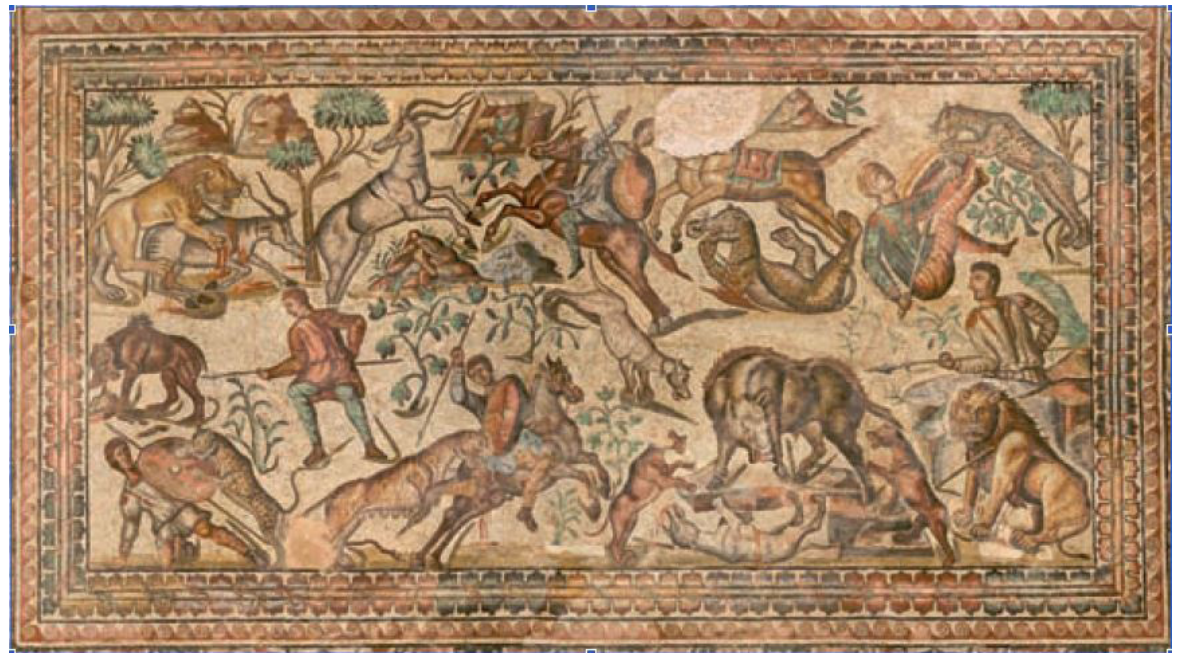

representing a hare hunt on a private estate in three stages (Fig. 17). It begins above with the hunters' departure on horseback and on foot in the upper register, followed by cornering of the prey with hounds in the middle zone, and finally the hunters' pursuit of the hare at full speed in the lower register. The triumphant gesture of the cavalier in the lower left corner, throwing open one arm as he looks out, is a common motif in African pavements and is paralleled on Roman sarcophagi.

In a later mosaic of $4^{\text {th }}$-century date in the main reception room of the Villa of La Olmeda (Regueras Grande 2013: 96 pl. 61), one observes a tableau of violent big-game hunting composed of several episodes arranged in interlocking registers (Fig. 18). The figures move freely over a white ground punctuated by landscape elements. The hunters are represented on horseback and on foot, and one mounted figure spears a lunging lioness, while nearby a large boar is brought to bay by yelping hounds. The boar's realistic twisting pose, seen in three-quarter view, emphasizes the animal's stubborn, truculent nature. In the upper left, a lion devours an antelope, a type of motif common to hunting mosaics in Spain and North Africa underscoring the ferocity of the chase. The scene also includes vignettes of hunters wounded or endangered in pursuit of their prey, such as a hunter falling backward (in the upper right), and another kneeling to defend himself with a shield against his attacker (in the lower left). The mosaic's bold style of draftsmanship and the abstract, simplified spatial illusion enhance the image's visual impact.

Other, more personalized hunting pavements also show different stages of the hunt in individual registers, such as a hunting party setting out for the chase, depicted in the Mosaic of Lord Julius from Carthage (Parrish 1984: 111-113 no. 9 pl.15-16), dated to the later $4^{\text {th }}$ century (Fig. 19). We see a dominus identified by name and mounted on horseback leading servants and hounds on an expedition, with the figures placed on either side of a fortified villa typical of contemporary design. Seasonal vignettes featuring both the master and his wife fill the pavement's corners, with one of these (autumn, in the lower right corner) showing a letter being delivered to the dominus. The entire pavement is a tableau of estate life. In the Small Hunt (Carandini - Ricci - de Vos 1982: 175-188 fig. 90-100 pl. XXIV) of $4^{\text {th }}$-century date at Piazza Armerina, there is depicted not only a scene of a religious sacrifice to Diana (in the upper zone) preceding the actual hunt, but also a picnic of aristocratic hunters under an awning who are served by attendants, as their horses are tethered to trees (Fig. 20). In another register of the 
Figure 19

Carthage, Mosaic of

Lord Julius. Tunis,

Musée du Bardo.

Figure 20

Piazza Armerina,

Mosaic of the Small Hunt. In situ.
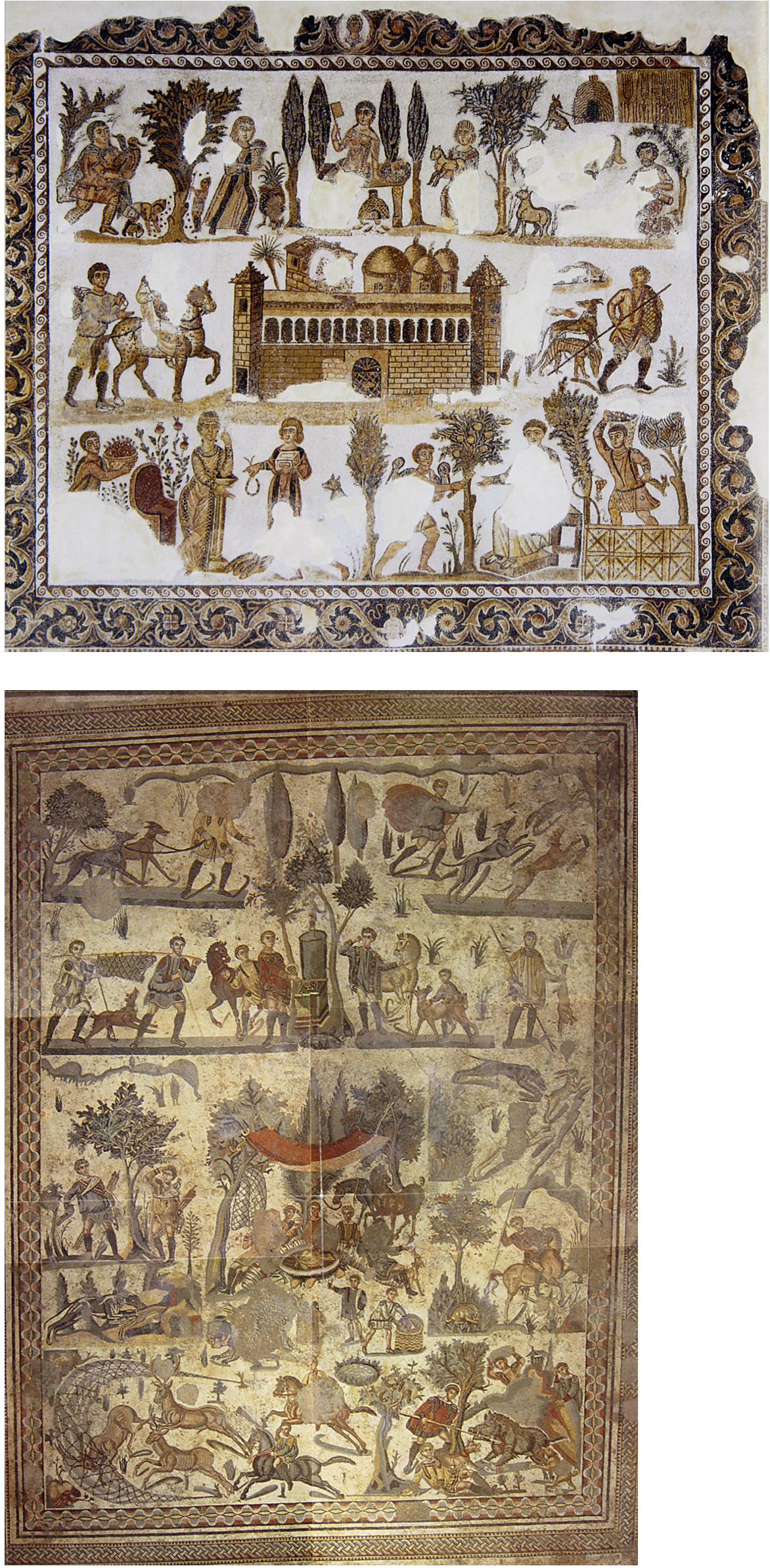


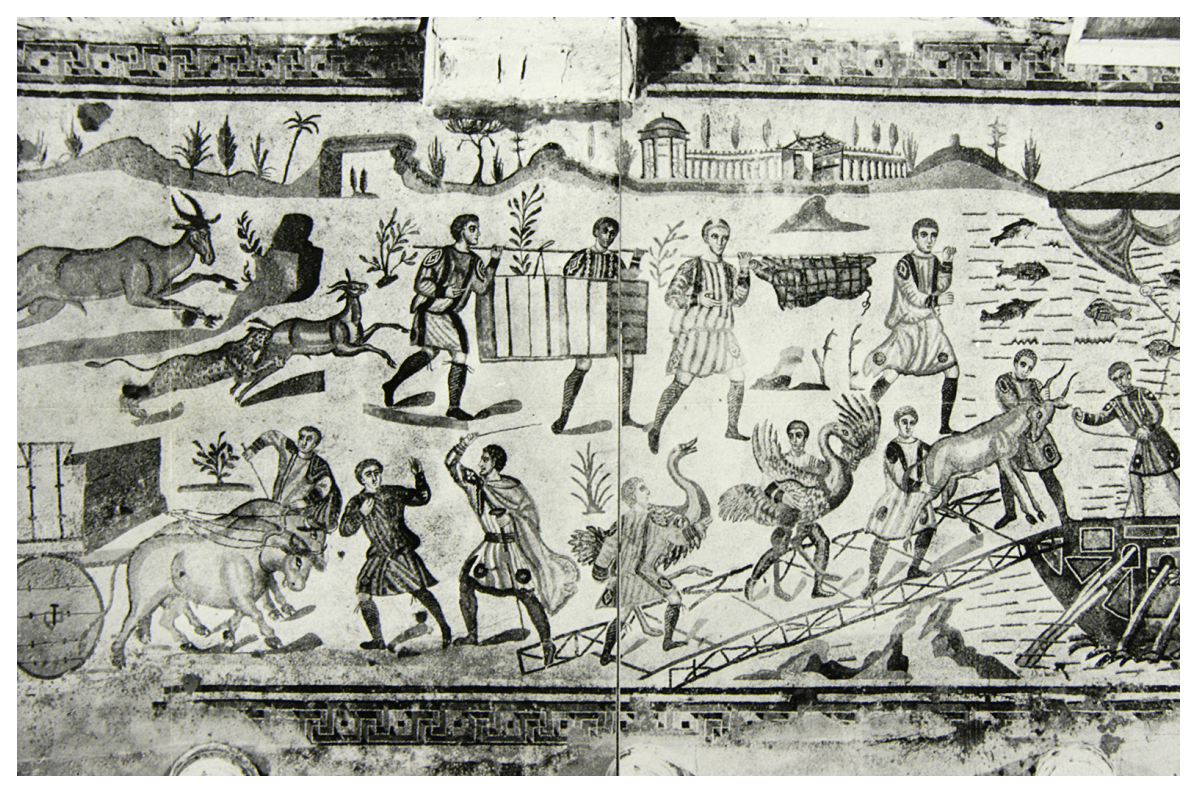

mosaic, the capture of stags and a wild boar is portrayed. This narrative of the progress of a hunt is picturesque and socially informative.

A different aspect of the hunt, namely, the capture of wild beasts for games in the amphitheater, is emphasized in other western mosaics. That subject is portrayed on a grand scale in the Great Hunt (Carandini - Ricci - de Vos 1982: 197-230 fig. 106-130 pl. XXVI-XXXI) paving a large corridor preceding the main reception space in the villa at Piazza Armerina (Fig. 21). The section of the frieze shown here depicts numerous hunters, all dressed in leggings and short ornamented tunics (one figure in the lower register also has a cloak), who transport captured animals to a ship and load them on board. One sees a boar carried upside down in a net, a wooden crate with animals inside, ostriches, and an antelope, as well as a wagon drawn by oxen. In the upper left are running gazelles, one of them pounced upon by a wild feline. Hunts of this magnitude presumably took place in North Africa and were a commercial enterprise supervised by the villa owner or an aide, whose portrait appears in another part of mosaic. Indeed, several other African hunting mosaics include the dominus of an estate in their imagery, as in a later $4^{\text {th }}$-century pavement from Djemila (Sintes - Ymouna 2003: 185 fig. on 185) in Algeria, which depicts both types of hunts, for sport and in the games, in condensed fashion (Fig. 22). Above, the landlord on horseback, centrally placed and flanked by a hound and a lioness, slays a wild boar on his latifundium, with his villa appearing in the background. A servant with a folded net and trapped hare stands to the left. In the lower part of the mosaic are several large animals, especially felines, which the landlord has supplied to the arena and which are speared by venatores with colorful costumes that include a square ornament on the front of the tunic; other animals are led off to one side.

The realistic, genre type of hunting imagery popular in mosaics of Spain, North Africa, and Sicily, of which we have seen a very limited selection, is supplemented by a smaller proportion of mythological hunts, especially those representing Meleager and the Calydonian Boar, Adonis, and the goddess Diana. Meleager, who died tragically in pursuit of his quarry, was considered by some viewers as the ideal hunter. One example is a $4^{\text {th }}$-century pavement from San Pedro dal Arroyo (Regueras Grande 2013: 85 fig. 52) near Avila in Spain. The nude Meleager, wearing boots and a cloak, charges the boar on foot, thrusting his spear forward in a conventional hunting pose, as his hounds converge on the
Figure 21

Piazza Armerina,

Mosaic of the Great Hunt, detail of one section. In situ.

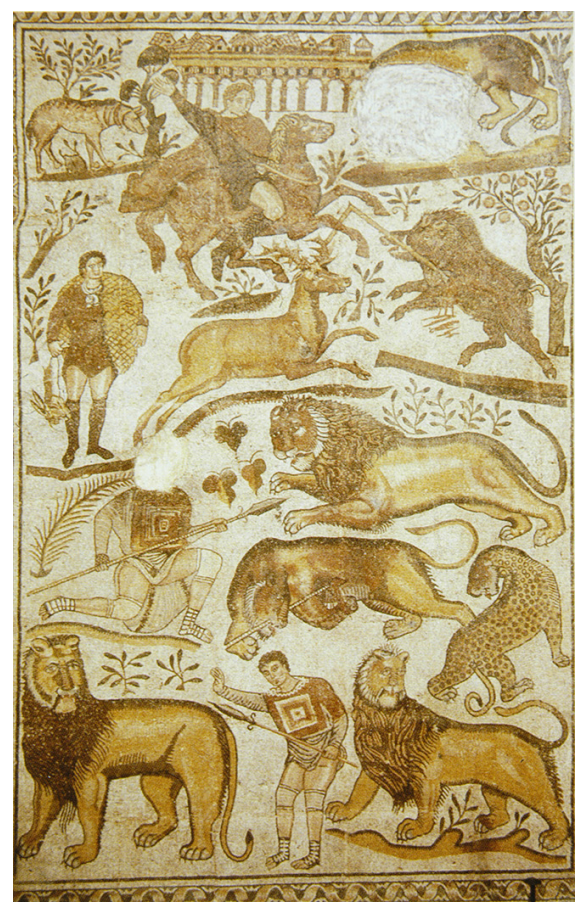

Figure 22

Djemila, Hunting mosaic. Musée archéologique de Djemila. 
Figure 23

Carranque, Villa of

Maternus, Mosaic with hunt of Adonis. In situ.

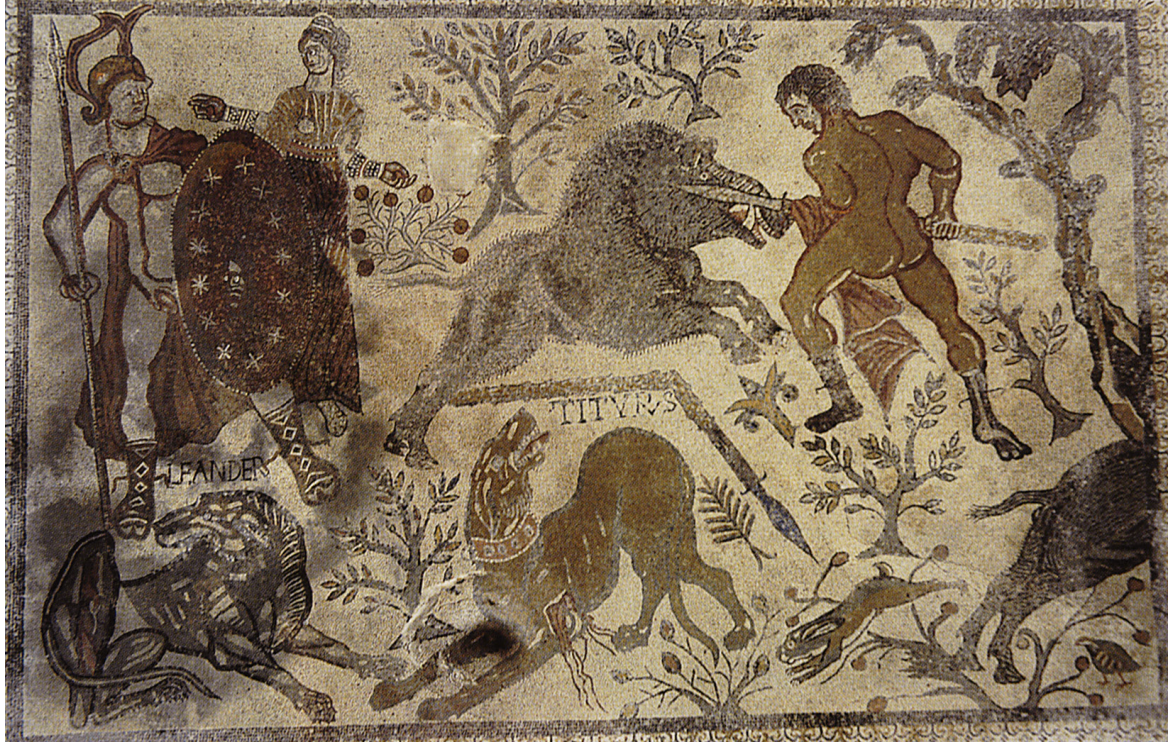

prey. A Latin inscription, Storia Meleagri, identifies the protagonist; in the upper right corner a partially clad woman, presumably Atalante, looks on, as does a second hunter behind Meleager. In a different $4^{\text {th }}$-century mosaic located in the center of the oecus of the Villa of Maternus at Carranque (Fernández-Galiano 2001: 87 fig. on 89), it is the nude Adonis, seen from behind, who appears lunging at a wild boar (Fig. 23). In the upper left appear the deities Venus and Mars, the latter of whom allegedly caused Adonis's death out of jealousy. The inscriptions Titurus and Leander designate the hunting hounds in the mosaic's lower zone. Finally, we mention Diana, who in a pavement of late $2^{\text {nd }}$-century date from Utica (Yacoub 1993: 258-259 fig. 189) stands wearing a short tunic and boots as she shoots an arrow at a hind in front of her; it is a gracefully composed scene. Diana also appears alongside Apollo in a $5^{\text {th }}$-century hunting pavement from Carthage (Dunbabin 1978: 57-58 pl. 35-37), the Mosaic of the Offering of the Crane, in which a sacrifice is made to the divine pair who patronizes and oversees the realistic hunts occurring around them, divided into registers. The central motif with the twin gods resembles the religious sacrifice to Diana in the Small Hunt at Piazza Armerina (Fig. 20).

Many of the innovations made by western mosaicists in representing the hunt theme had a direct influence on eastern craftsmen of the mid- to late empire, creating an international artistic koine for this subject. After demonstrating this development with selected examples, we shall mention one other key innovation, compositionally, which originated in the west and foreshadowed important changes in the east. Already in the House of Dionysos at Paphos (Kondoleon 1994: 294 fig. 186-188) of late $2^{\text {nd }}$ to early $3^{\text {rd }}$ - century date, there appear episodes of the venationes in panels decorating the building's peristyle. One panel depicts a crouching hunter who wears a long-sleeved tunic and leggings spearing a bull (Fig. 24). Presumably, the mosaic patron sponsored public spectacles of this type. Other eastern pavements of later date show hunting for sport, in the pursuit of small game or large prey. That is true of the superb Great Hunt from the "Triclinos Building" at Apamea (Balty 1977: 104-109 nos. 47-49 fig. on $105,107,109)$, dated to the first quarter of the $5^{\text {th }}$ century and now kept in Brussels (Fig. 25). A series of hunting episodes rises effortlessly in interlocking registers, beginning with a hare hunt below and leading to two animal combats, one of a lion with a fallen stag and the other of a leopard attacking a wild boar. 


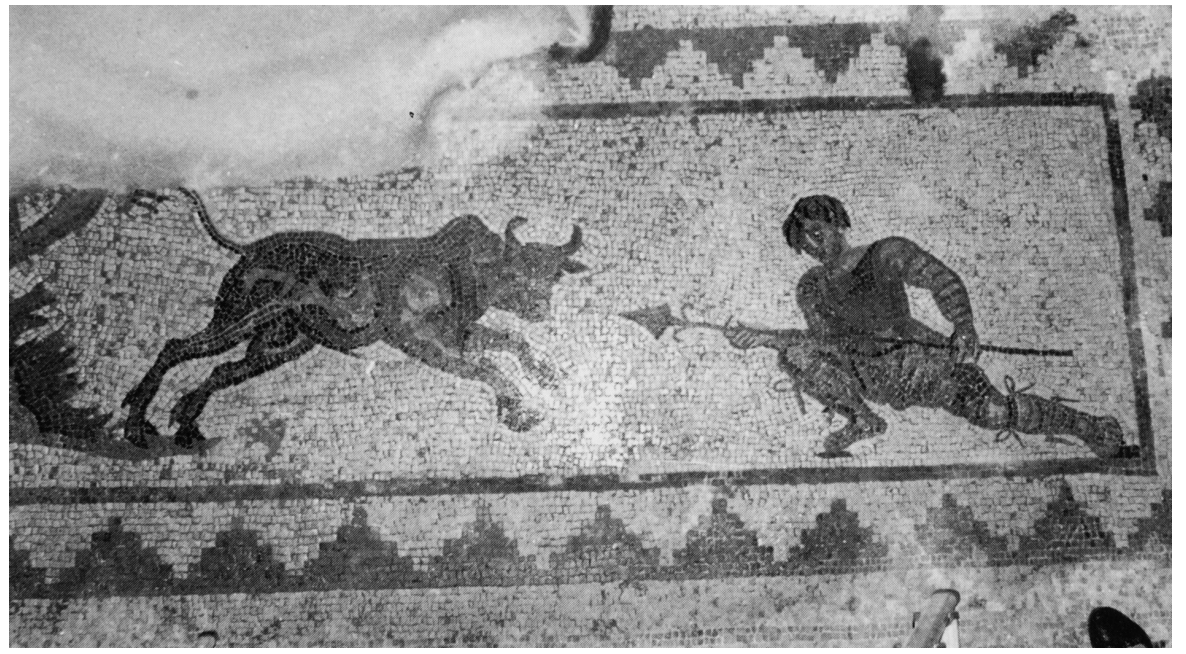

Figure 24

Paphos, House of Dionysos,

Mosaic with scene of venationes. In situ.

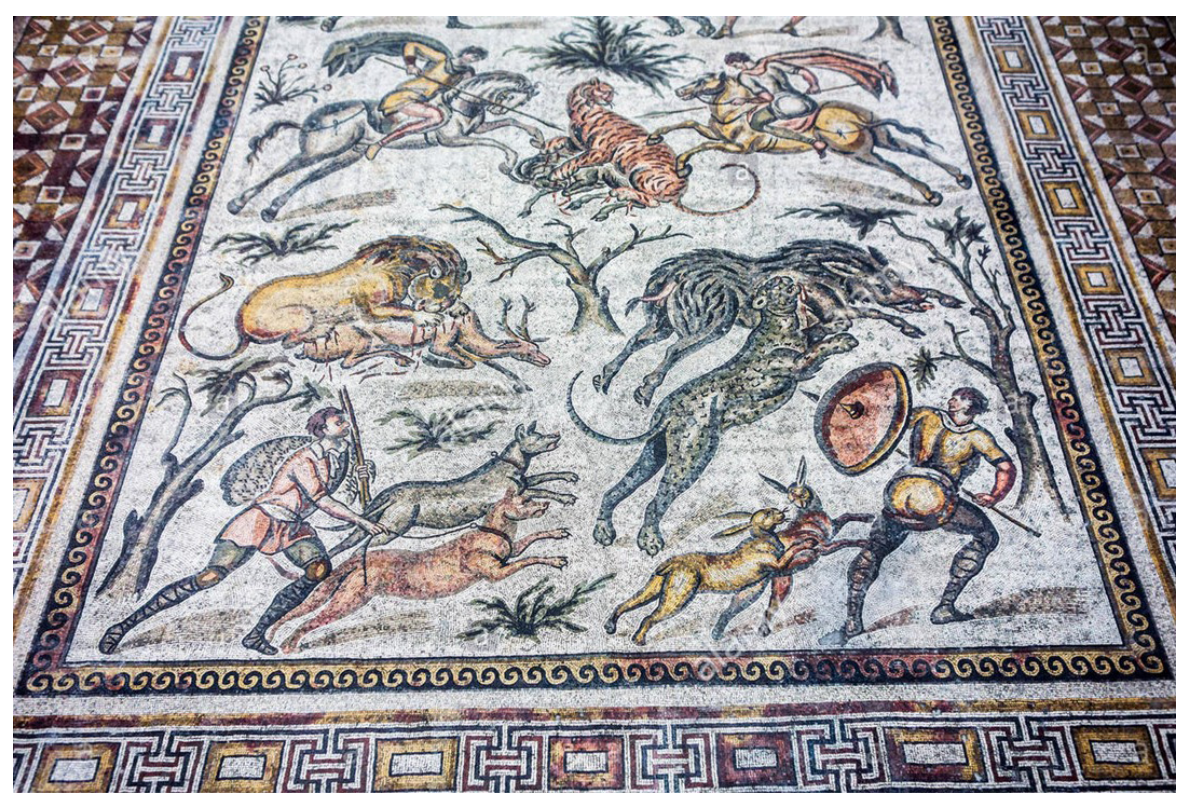

Figure 25

Apamea, Mosaic of the Great Hunt. Brussels, Musées royaux d'art et d'histoire.

At the pavement's mid-point, a beautiful seated tiger with its prey turns its head, growling at two inward-facing horseman with spears who race toward it; it is the design's emotional climax. Higher up are more hunting vignettes that depict archers, felines, and a bear. This mosaic forms an impressive counterpart to the pavements from La Olmeda (Fig. 18) and Djemila (Fig. 22), appearing more formally arranged than they and having a central vertical axis.

In eastern mosaics, there also is a strong interest in depicting mythological hunters, among them Amazons, who have a long history of representation in the Greek east ${ }^{9}$. In fact, the same building at Apamea that yielded the Great Hunt also produced a somewhat later mosaic of hunting Amazons (Balty 1977: 114-117 nos. 52-53 fig. on 115, 117) (Fig. 26). Within a horizontal panel, two Amazons are seen riding in a landscape pursuing a leopard and a lion, and they carry spears and pelta-shaped shields. The design has a staccato rhythm so different from western pavements. Far more imposing is a large mosaic of the late $5^{\text {th }}$ or early $6^{\text {th }}$ century in the Villa of the Amazons at ancient Edessa (Karabulut

9 See Von Bothmer 1957, discussing representations in a variety of media. 
Figure 26

Apamea, Mosaic of Amazons hunting. Brussels, Musées royaux d'art et d'histoire.
Figure 27

Edessa, Villa of the Amazons, Mosaic of Amazons hunting. Şanliurfa, Haleplibahçe Mosaic Shelter.

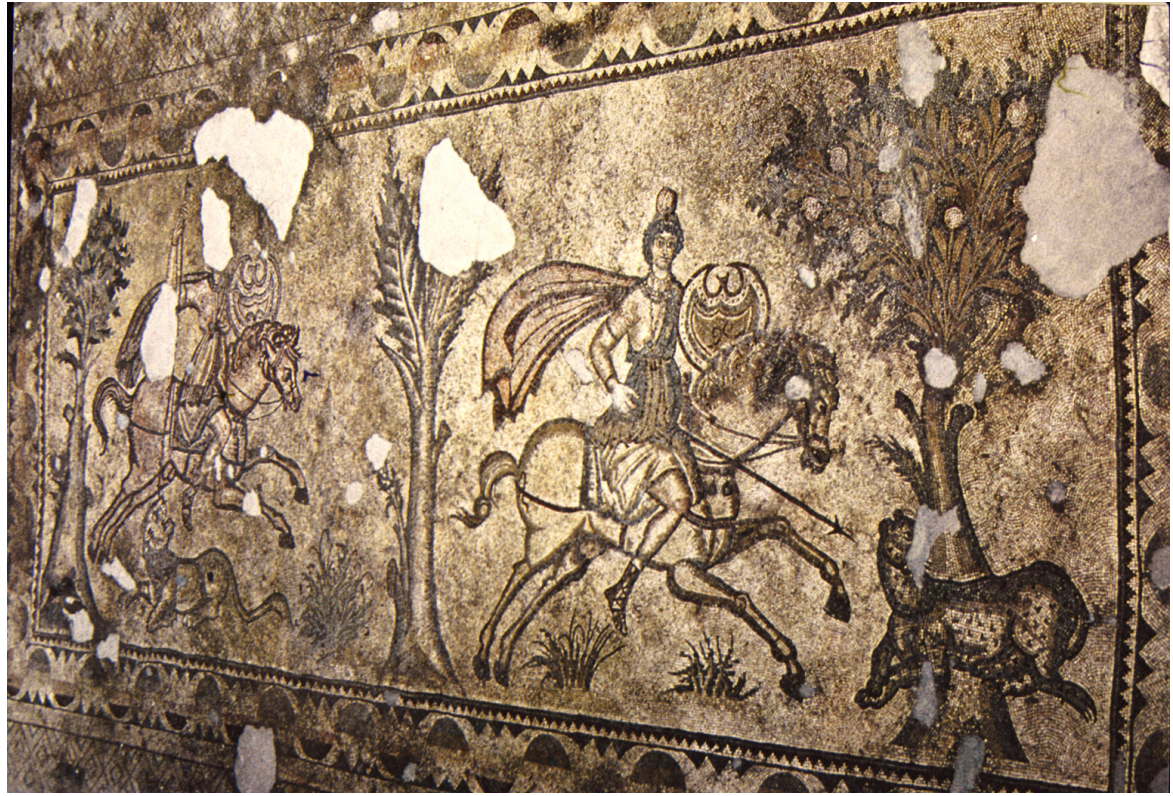

et al. 2011: 55-68 photos 60-81, front cover of book) (modern Şanliurfa), which depicts four Amazon queens in a landscape divided into three registers and punctuated by fruit-bearing trees and rocks (Fig. 27). The women energetically attack a variety of wild felines and an ostrich, moving on foot and on horseback and using an ax, spear, long sword, or bow and arrow as weapons. One hunter in the lower right twists in her saddle as she takes a Parthian shot. The names of three of the Amazons are preserved, including Hippolyte, Melanipe (Fig. 28, detail of Melanipe), and Thermodosa (partly obliterated). All of the figures in the mosaic, human and animal, are loosely arranged in symmetrical fashion around a wounded lioness in the center, from which blood pours. The mosaic's lower register contains additional felines and hounds. (Close examination of the pavement's white ground reveals a scale pattern typical of many late mosaics from the east.) Also popular in hunting mosaics from the orient is Artemis, typically represented as an active huntress, as we see in a mosaic carpet from Sarrîn (Balty

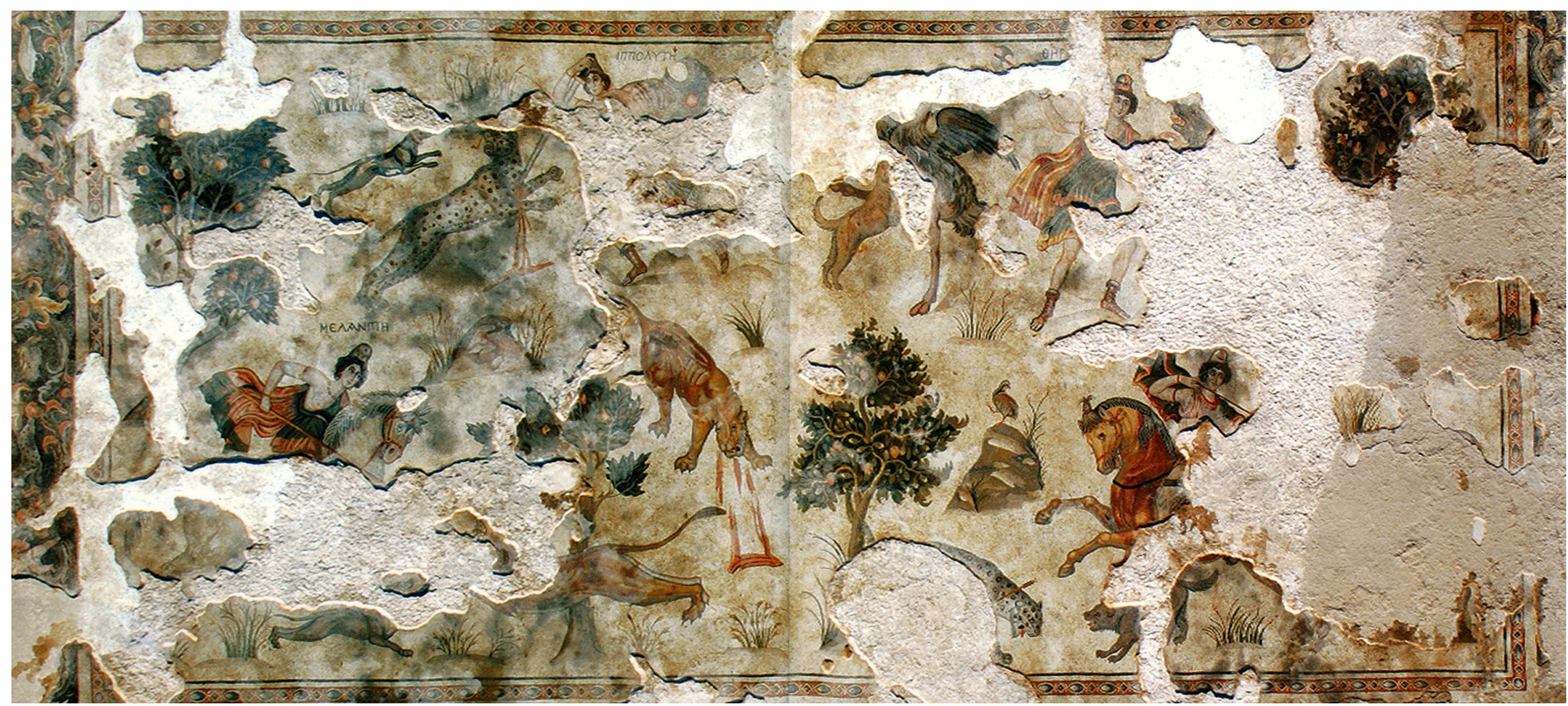




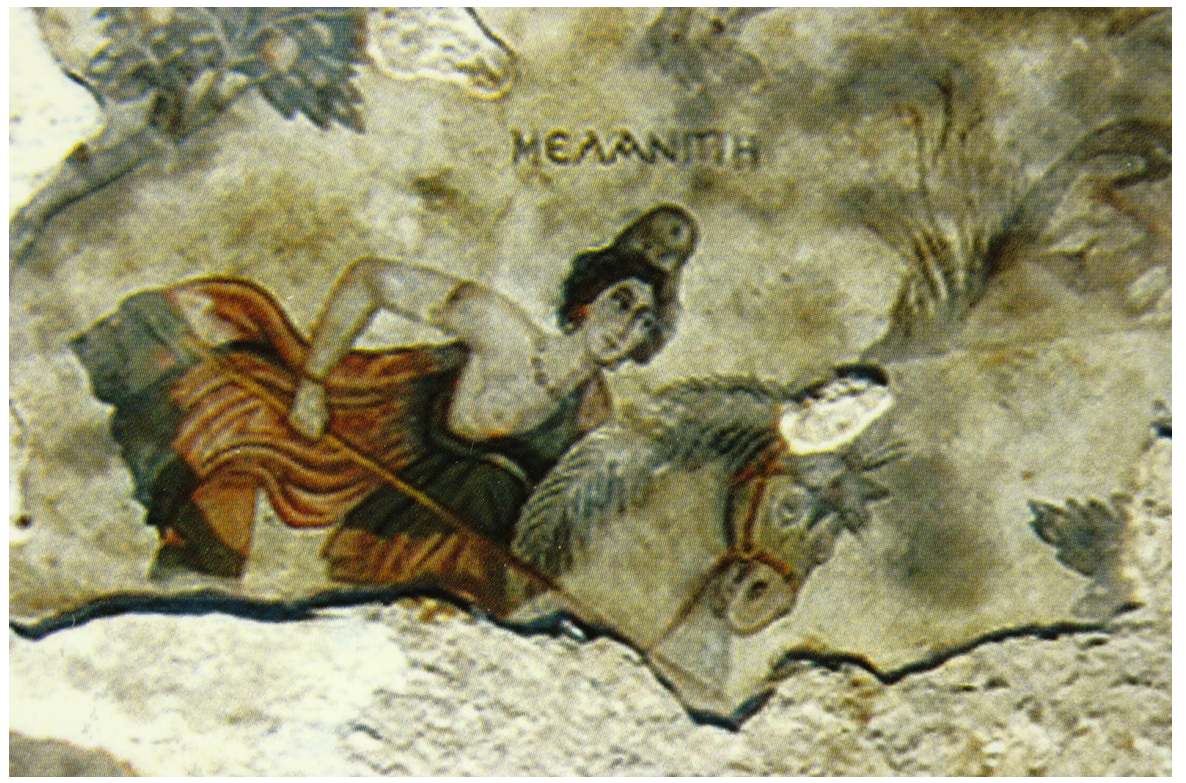

Figure 28

Edessa, Mosaic of Amazons hunting, detail of Melanipe.

1990: 3-5, 24-26 pl. II col. pl. E,2 $)^{10}$, ornamenting the same building where a Dionysiac pavement mentioned above (Fig. 11) also occurred.

Besides Amazons, the mythological hunts depicted in eastern mosaics also include the heroes Meleager and Atalante, already noted for the west in the $4^{\text {th }}$ century (San Pedro del Arroyo). During that same century the mythical couple were represented in a mosaic from the Constantinian Villa at Antioch, illustrated infra in Fig. 33. There Meleager is shown nude. However, in some $5^{\text {th }}$-century eastern pavements (as noted by J. Balty), Meleager is depicted fully draped in late antique fashion, wearing a long-sleeved tunic and cloak, and riding on horseback as he spears his animal foe. In a mosaic from Apamea (Balty 1977: 118-123 nos. 54-56 fig. on 54-56, - 119, 123, 123; Raeck 1997: 34 abb. 4), the hero even has a Persian cap, and in a pavement from Halikarnassos (Hinks 1933: 127 no. 51 , a fig. 147 [Meleager], with a matching panel of Atalante, 129, no. 51,b fig. 147; Raeck 1997: 39 abb. 1-2; Scheibelreiter-Gail 2011: 271), he is identified by name.

One other major contribution of western mosaicists to the repertory of hunting pavements was to create floors of centralized or circular design, affording multiple views of the subject represented rather than having a fixed viewpoint. An early example of the former type, having a circle-in-square arrangement, is a mosaic from Conimbriga (Bairrão Oléiro 1992: 104-109 pl. 38-39) dated to the end of the $2^{\text {nd }}$ to early $3^{\text {rd }}$ century (Fig. 29). Within the central emblema, hunters on horseback and their hounds pursue a stag and a doe in a radial arrangement, with trees placed between the figures. The two hunts can be viewed from opposite sides of the panel.

In Roman Gaul, a centralized format for hunting pavements was developed more fully, with an emblema of mythological content placed in the middle and framed by realistic hunting episodes on the pavement's four sides; the episodes face in various directions. Our first Gallic example is a mosaic from Villelaure (Lavagne 2000: 311-316 no. 916 pl. CII-CIII; Belis 2016: 23-24 fig. 14), perhaps made in the last quarter of the $2^{\text {nd }}$ century, and its central panel has an image of Diana and

10 In another panel of the pavement, Meleager and Atalante are represented as lovers seated in a landscape, Balty 1990: 1-12, 54-57 pl. XXIV col. pl. E,3. 
Figure 29

Conimbriga, House of the

Fountains, Hunting mosaic. In situ. Photo courtesy of Flickr.com and Virgilio Correia.

Figure 30

Lillebonne, Mosaic of stag hunt. Rouen, Musée départemental des Antiquités. Photo By Gérard - Own work, CC BY-SA 4.0, https://commons//commons.wikimedia.org/ w/index.php?curid=37263962.
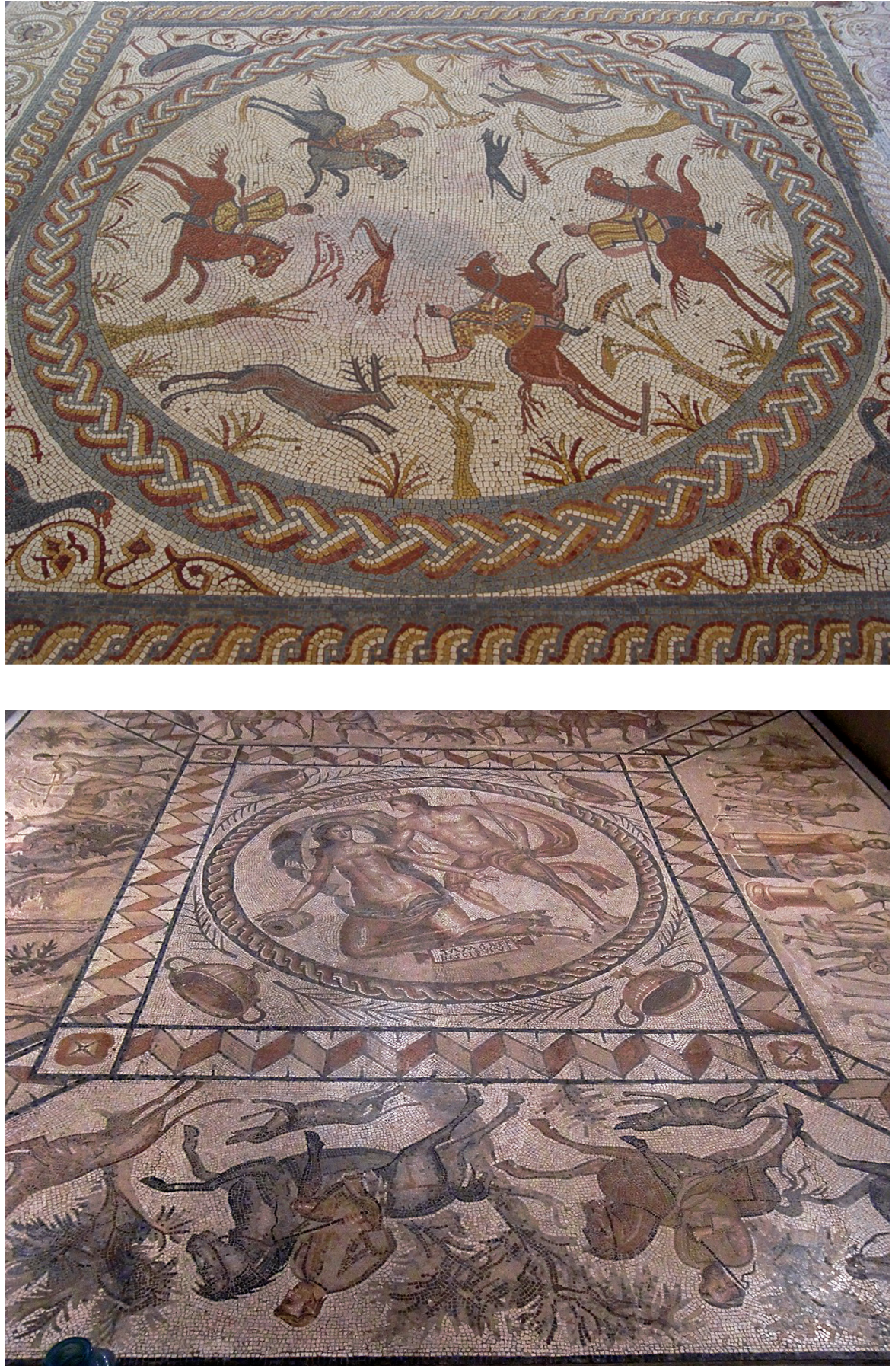

Callisto; outward-facing hunts of a lion, stags, and a boar occur along the edges of the field. Diagonally set trees in the corners separate the scenes. Equally impressive is a late $3^{\text {rd }}$-century hunting pavement from Lillebonne (Darmon 1994: 90-102 no. 885 pls. LXVII-LXXXIX) in northern Gaul, which has a central medallion with a mythical love scene, surrounded by four inward-turned friezes that show successive episodes of a stag hunt (Fig. 30). One of the latter (on the pavement's right side) depicts a sacrifice to the goddess Diana, with several figures in plain dress standing around an altar (Fig. 31, central part of the sacrifice), a scene recalling the religious sacrifice in the Small Hunt at Piazza Armerina (Fig. 20). At Lillebonne, diagonally placed geometric bands divide the hunting vignettes from each other. 

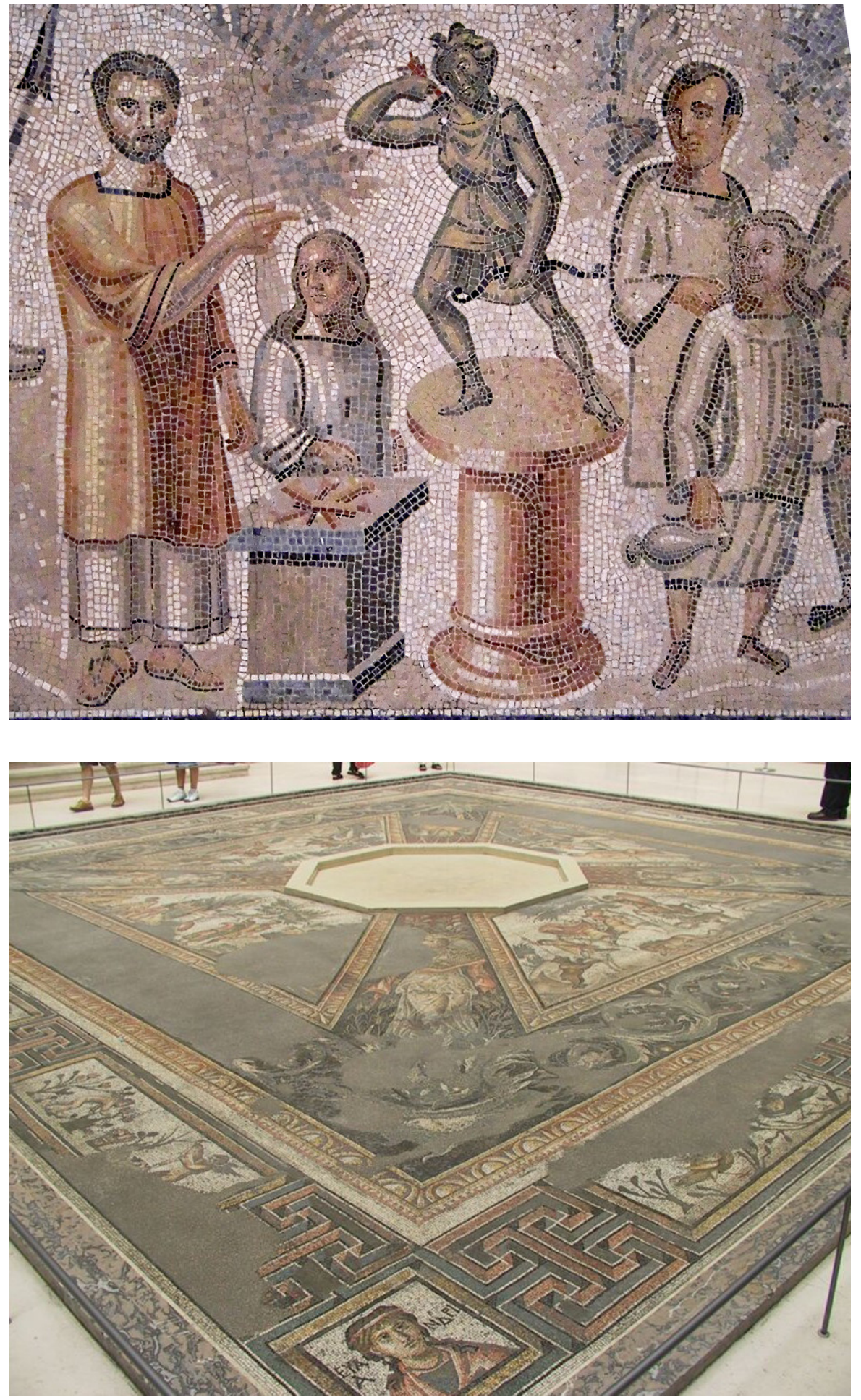

These compositional and iconographic changes had an impact in the east, as we observe in the pavement from the Constantinian Villa (Baratte 1978: 99-118 no. 45 fig. 94-125) at Antioch, now kept in the Louvre (Fig. 32). A series of individual hunting scenes faces outward from a central octagon where there was a pool or fountain, and they are separated by elegant, standing female personifications of the seasons, each framed by plant sprays and carrying the fruits of her time of the year. Of the four hunting episodes, one depicts the nude Meleager and Atalante in a landscape, and the hero charges the boar, lunging forward with his spear lowered; Atalante, who wears a short tunic and boots, attacks a lion with a
Figure 31

Lillebonne, Mosaic of stag hunt, detail of religious sacrifice. Photo By Gerard - Own work, CC BY-SA 4.0, htps://commons.wikimedia.org/w/index. php?cuid=37275496.

Figure 32

Antioch, Constantinian Villa,

Mosaic with hunting scenes and season personifications. Paris, Musée du Louvre. 

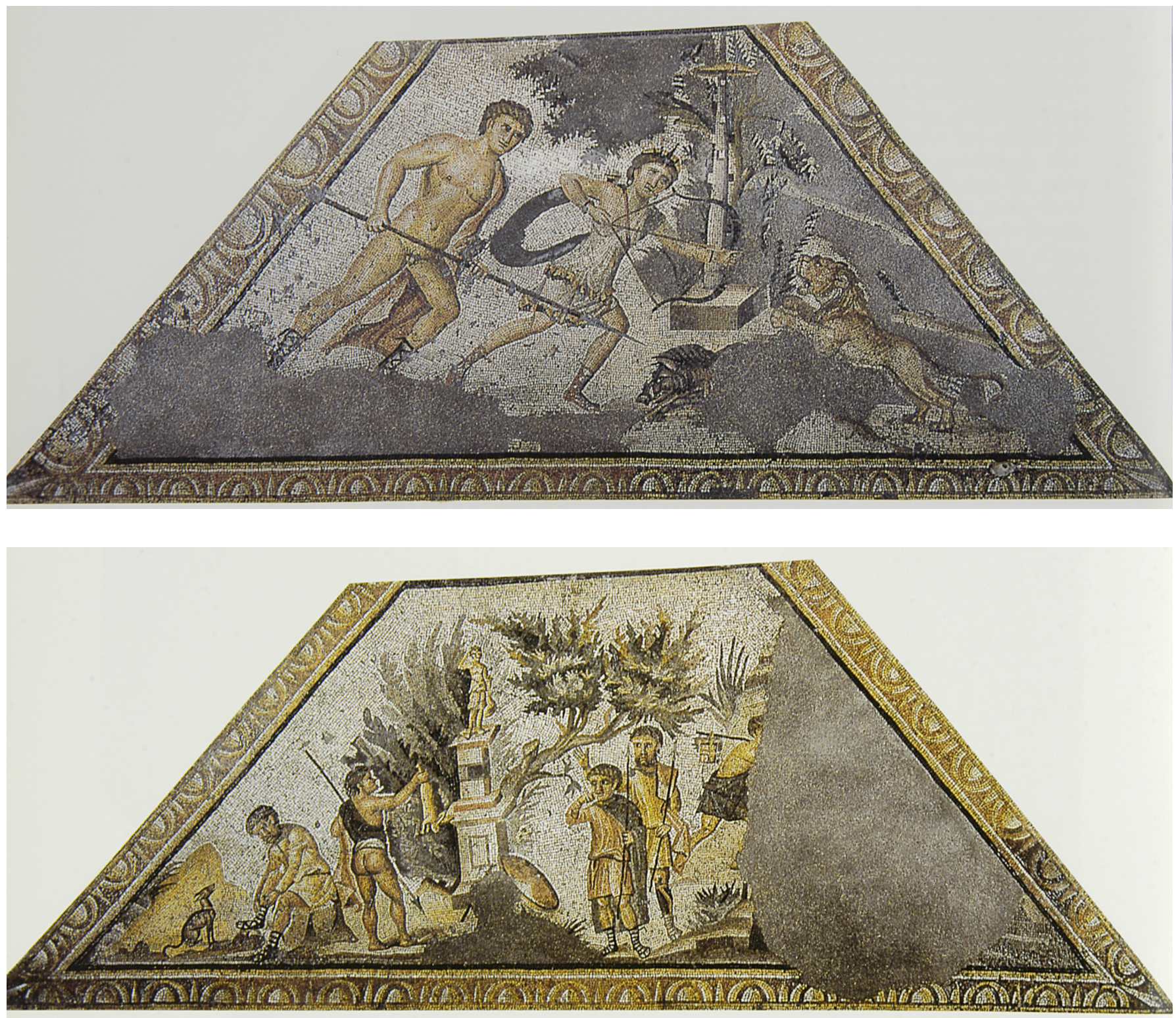

Figure 33

Antioch, Constantinian Villa, Mosaic with hunting scenes, detail of Meleager and Atalante.

Figure 34

Antioch, Constantinian Villa, Mosaic with hunting scenes, detail of religious sacrifice. bow and arrow (Fig. 33). The other three hunting episodes are of a realistic type, and one includes a religious sacrifice to Artemis (Fig. 34), comparable to what we saw in the stag hunt from Lillebonne (Fig. 31). Finally, the outermost frieze of the Antioch pavement contains bucolic scenes and corner bust figures symbolizing virtues of the mosaic patron. One of the latter is labeled Euandria or "Manliness" (Baratte 1978: 99 fig. 98), the equivalent of the Latin virtus, and she is shown in the nearest corner of Fig. 32. Thus, in the magnificent mosaic from the Constantinian Villa, the theme of the hunt has several associations, especially with the bounty of the seasons, and it glorifies the patron in an allegorical manner different from the more direct, descriptive imagery of western hunting pavements. In fact, the use of allegorical busts became increasingly common in later mosaics from Antioch, not only those representing the hunt.

In the later $5^{\text {th }}$ and $6^{\text {th }}$ centuries, hunting mosaics of centralized design from Antioch acquired a more simplified format, eliminating frames around the hunting episodes and placing inward-pointing trees in the pavement's corners, a development anticipated a few centuries earlier at Conimbriga (Fig. 29) and at Villelaure (Belis 2016: fig. 14). In the Mosaic of Megalopsychia (Lassus 1969: 


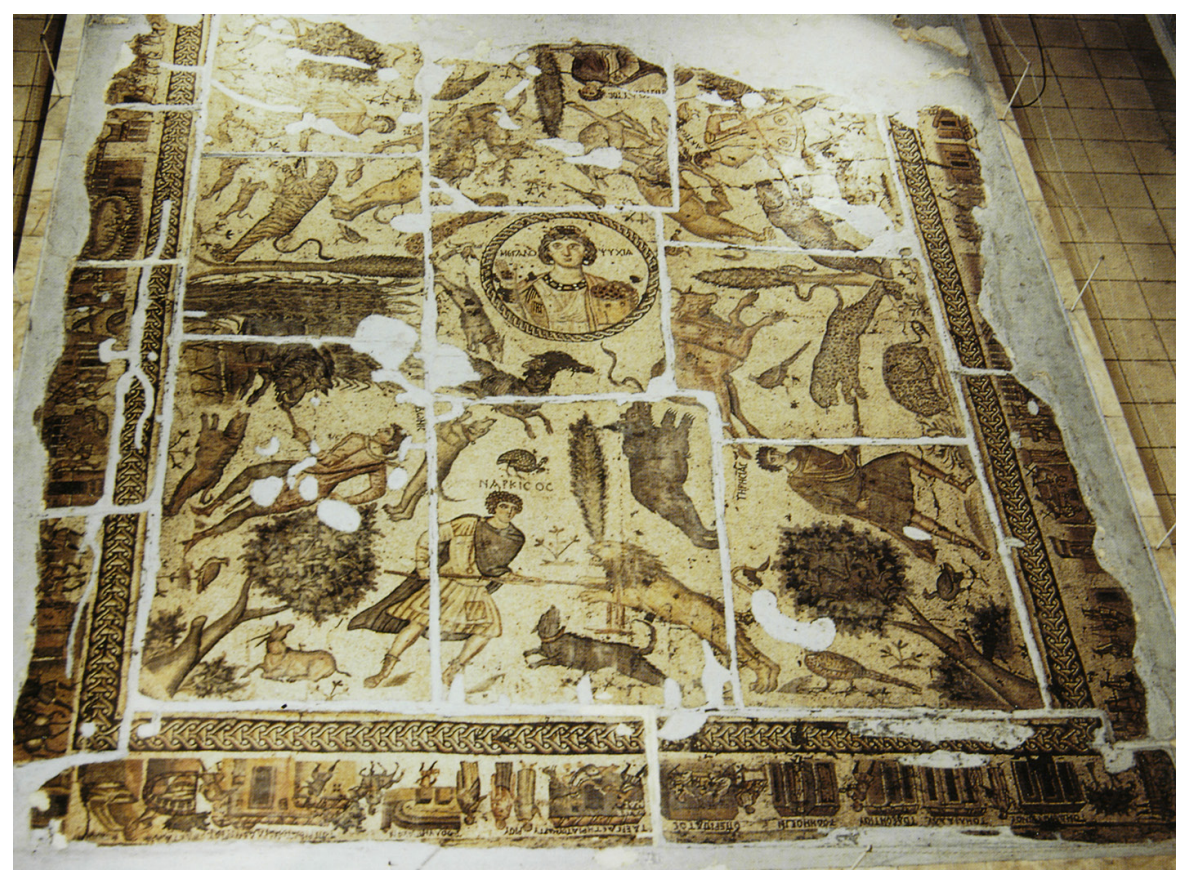

139-146 pls. LXIII-LXVI; Dunbabin 1999: 180-183 figs. 194-195; Cimok 2000: 251-274 fig. on these pages) of mid- to later $5^{\text {th }}$-century date from Antioch, there appears a central female bust with that name who offers a coin and holds a container full of money, and who apparently alludes to the patron's "largeness of mind" or generosity (Fig. 35). Encircling her is a series of animal combats. Further from the center on the mosaic's four sides are outward-facing scenes of hunters on foot spearing rampant beasts such as a lion, a leopard, and a wild boar. The men are identified by mythical names including Narkissos, Adonis, and Teresias, and are separted by trees. J. Lassus suggested that these vignettes refer to venationes sponsored by the mosaic owner, whose generosity is represented by the central bust. K. Dunbabin went a step further, claiming that the hunters' costumes are characteristic of the arena. However, their dress contrasts with the clearly identifiable venatores in the $6^{\text {th }}$-century Great Palace Mosaic (Cimok 1997: 14-15 no. 2 fig. on these pages; Jobst et al. 1997: 45 fig. 21-22) from Constantinople, who wear the sleeved tunic, short trousers, and leggings characteristic of hunters in the amphitheater. By contrast, several of the Antioch figures have longer tunics, cloaks, and boots typical of aristocratic hunters in late antiquity (cf. the figure Meleager in a mosaic from Halikarnassos, Hinks 1933: fig. 147). Might not the mythical hunters in the Antioch floor glorify the hunting prowess of the mosaic patron by alluding to literary heroes of the chase? Megalopsychia may, as Lassus (Lassus 1969: 139-140) also proposed, refer to the patron's financing of the reconstruction of buildings at Antioch, seen in the pavement's topographical border, which had recently been destroyed by an earthquake.

Just as compelling is the $6^{\text {th }}$-century Worcester Hunt (Levi 1947: 364-365 fig. 151 pl. LXXXVI,b, CLXX-CLXXIII; Kondoleon 2000: 65 fig. 2; 158159 fig. 1; 219) from Antioch, which has a circular design like the Mosaic of Megalopsychia, with hunters and their prey distributed evenly over an abstract white ground, forming a "carpet style"11 (Fig. 36). In this example, we see

11 On the use of this term, see Lavin 1963: 195. 
Figure 36

Antioch, Worcester Hunt. Worcester Art Museum.

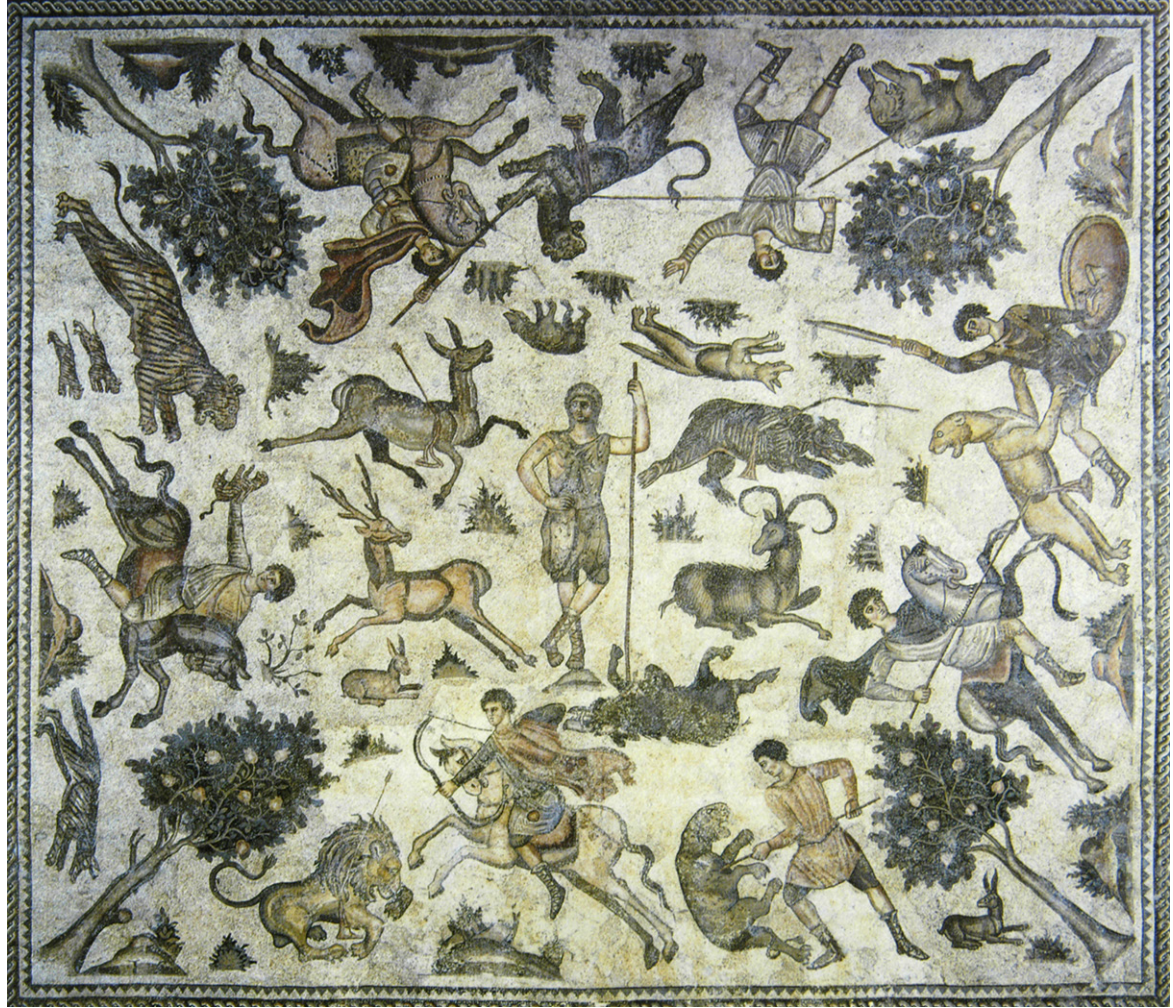

hunters both on horseback and on foot attacking wild animals with spears and bows and arrows; fruit-laden trees occupy the pavement's corners. In the center a hunter in short tunic and leggings stands triumphantly with his legs crossed and one arm akimbo as he spears a dead boar lying at his feet. Doro Levi (Levi 1947: 344) thought the man might be an ideal, princely hunter with Hellenistic antecedents; he has no counterpart in hunting pavements of the Roman west. A circle of animal victims and other creatures surrounds the figure in the Antioch floor. The hunting episodes on the mosaic's perimeter are finely composed and show originality. In a poignant scene of the left side, a hunter on horseback lures a growling tigress from its den by holding out one of its cubs as he races away. On the right side, a leaping panther mauls a fallen hunter and turns its head toward an advancing horseman threatening the animal with a spear. The latter group recalls both a fallen hunter in the mosaic from La Olmeda (Fig. 18) and the motif of a tigress attacked by two horsemen with spears in the Great Hunt from Apamea (Fig. 25).

\section{Conclusion}

In this article, we have followed the development of a few artistic themes in mosaics of the east and west, being very selective in our examples and showing how craftsmen adapted these themes in each zone. In the case of Dionysos's triumph, the direction of artistic influence first traveled from west to east, but in late antiquity draftsmen in the orient added new references to the mysteries that seem to reflect the rituals' continued practice in parts of that region. In the $5^{\text {th }}$ century, eastern mosaicists also influenced the design of at least one Spanish pavement, partially reversing earlier trends. As for the theme of the hunt, models initially progressed from west to east, but local preferences soon emerged, with the west favoring bold realism, often personalized. The east, while borrowing 
many of the west's innovations, had a greater interest in making mythological and allegorical references in its hunting imagery, while updating figures' dress in some instances. These differences reflect varied historical and economic circumstances in the two geographic zones, as well as the taste of local patrons and the artistic legacy of the past.

\section{Bibliography - Kaynaklar}

Abadie-Reynal - Ergeç 2012 C. Abadie-Reynal - R. Ergeç (co-dir.), Zeugma I. Fouilles de l'habitat (1), La mosaïque de Pasiphaë, Paris, De Boccard Edition - Diffusion.

Bairrão Oléiro 1992 J. M. Bairrão Oléiro, Conimbriga. Casa dos Repuxos. Corpus dos mosaicos romanos de Portugal, Conventus Scallabitanus I, Conimbriga.

Balty 1977

J. Balty, Mosaïques antiques de Syrie, Brussels, Musées royaux d'art et d'histoire.

Balty 1990

J. Balty, La mosaïque de Sarrîn (Osrhoène), Paris, Librairie Orientaliste Paul Geuthner.

Baratte 1978

F. Baratte, Catalogue des mosaïques romaines et paléochrétiennes du musée du Louvre, Paris, Editions de la Réunion des musées nationaux.

Belis 2016

A. Belis, Roman Mosaics in the J. Paul Getty Museum, Los Angeles, J. Paul Getty Museum.

Blanchard-Lemée 2005

M. Blanchard-Lemée, "Le triclinium à la mosaïque dionysiaque de Sétif (Algérie)", CMGR IX,1, 291-301.

Blanchard-Lemée et al. 1995

M. Blanchard-Lemée - M. Ennaïfer - Hédi et Latifa Slim, Sols de l’Afrique romaine. Mosaïques de Tunisie, Paris, Imprimerie Nationale Editions.

Carandini - Ricci - de Vos 1982

A. Caarandini - A. Ricci - M. de Vos, Filosofiana, la villa di Piazza Armerina. Immagine di un aristocatico romano al tempo di Costantino, Palermo, S. F. Flaccovio, Editiore.

Cimok 1995

F. Cimok (ed.), Antioch Mosaics, İstanbul, A Turizm Yayınları.

Cimok 1997

F. Cimok, Mosaics in İstanbul, İstanbul, A Turizm Yayınları.

Cimok 2000

F. Cimok, Antioch Mosaics, a Corpus, İstanbul, A Turizm Yayınları.

Dalgıç 2015

Ö. Dalgıç, "The Triumph of Dionysos in Constantinople. A Late $5^{\text {th }}$-Century Mosaic in Context”, DOP 69, 15-47.

Darmon 1994

J.P. Darmon, Recueil général des mosaïques de la Gaule II, fasc. 5, Paris, Editions du Centre National de la Recherche Scientifique.

Daszewski 1985

W. Daszewski, Dionysos der Erlöser. Griechische Mythen in spãtantiken Cypern, Mainz, Verlag Philipp Von Zabern.

Dunbabin 1971

K. Dunbabin, "The Triumph of Dionysus on Mosaics in North Africa", PBSR 39, 52-65.

Dunbabin 1978

K. Dunbabin, Mosaics of Roman North Africa. Studies in Iconography and Patronage, Oxford, Clarendon Press.

Dunbabin 1999

K. Dunbabin, Mosaics of the Greek and Roman World, Cambridge, Cambridge University Press.

Dunbabin 2008

K. Dunbabin, "Domestic Dionysos? Telete in mosaics from Zeugma and the late Roman Near East", JRA 21, 193-224.

Fernández-Galiano 1984

D. Fernández-Galiano, "El triunfo de Dioniso en mosaicos hispanorromanos”, AEspArch 57, 97-120.

Fernández-Galiano 2001

D. Fernández-Galiano, Carranque. Centro de Hispania romana, Madrid, Museo Arqueológico Regional de la Comunidad de Madrid.

García y Bellido 1965

A. García y Bellido, "Los mosaicos de Alcolea (Córdoba)”, BRAH 156, 7-19.

Guardia Pons 1992

M. Guardia Pons, Los mosaicos de la antigüedad tardía en Hispania; estudios de iconografía, Barcelona, Poblagràfia, S.A.

Hinks 1933

R. Hinks, Catalogue of the Greek, Etruscan and Roman Paintings and Mosaics in the British Museum, London, Trustees of the British Museum.

Jobst et al. 1997

W. Jobst - E. Bahçet - C. Gurtner, Istanbul, Das grosse byzantinische Palastmosaik, İstanbul, Arkeoloji ve Sanat Yayınları. 
Karabulut et al. 2011

Kondoleon 1994

Kondoleon 2000

Lancha - Andréé 2000

Lassus 1969

Lavagne 2000

Lavin 1963

Levi 1947

Ling 1998

López Monteagudo 1998

Matz 1968

Önal 2002

Ovadiah et al. 1991

Pandermalis 1997

Parrish 1984

Picard 1948

Raeck 1997

Regueras Grande 2013

Ridgway 1990

Scheibelreiter-Gail 2011

Sintes - Ymouna 2003

Talgam - Weiss 2004

Tarradell 1969

Valero Tévar 2013

Vargas Vázquez 2014

Von Bothmer 1957

Weinberg 1960

Willers 1987

Yacoub 1993

Yacoub 1995
H. Karabulut - M. Önal - N. Dervişoğlu, Haleplibahçe Mozaikleri, Şanliurfa/Edessa, İstanbul, Arkeoloji ve Sanat Yayınları.

C. Kondoleon, Domestic and Divine. Roman Mosaics in the House of Dionysos, Ithaca/London, Cornell University Press.

C. Kondoleon, Antioch, The Lost City, Princeton, Princeton University Press.

J. Lancha - P. L. André, Corpus des mosaïques romaines du Portugal II, Conventus Pacensis: La villa de Torre de Palma, Lisbon.

J. Lassus, “Antioche en 459, d'après la mosaïque de Yakto”, Janine Balty (ed.), Apamée de Syrie, bilan de recherches archéologiques 1965-1968, Brussels, Musées royaux d'art et d'histoire, 139-146.

H. Lavagne, Recueil général des mosaïques de la Gaule III. fasc. 3, Paris, Editions du Centre National de la Recherche Scientifique.

I. Lavin, “The Hunting Mosaics of Antioch and Their Sources”, DOP 17, 180-286.

D. Levi, Antioch Mosaic Pavements 2 vols., Princeton, Princeton University Press.

R. Ling, Ancient Mosaics, Princeton, Princeton University Press.

G. López Monteagudo, "Sobre una particular iconografía del triunfo de Baco en dos mosaicos romanos de la Bética”, Annales de Arqueología Cordobesa 9, 191-222.

F. Matz, Die dionysischen Sarkophage II, Berlin, Gebr. Mann Verlag.

M. Önal, Mosaics of Zeugma, İstanbul, A Turizm Yayınları.

A. Ovadiah - C. Gomez de Silva - S. Mucznik, "The Mosaic Pavements of Sheik Zouède in northern Sinai", Tesserae. Festschrift für Josef Engemann, Münster Westfalen.

D. Pandermalis, Dion. The Archaeological Site and the Museum, Athens, Adam Editions.

D. Parrish, Season Mosaics of Roman North Africa, Rome, Giorgio Bretschneider Editore.

G.-C. Picard, "Dionysos victorieux sur une mosaïque d'Acholla”, RA II, 810-821.

W. Raeck, "Mythos und Selbstdarstellung in der spätantiken Kunst. Das Beispiel der Meleagersage", S. Isager - B. Poulsen (eds.), Patron and Pavements in Late Antiquity, Odense, Odense university Press, 30-37.

F. Regueras Grande, Villas romanas del Duero. Historia de un paisaje olvidado. Valladolid, Cargrat.

B. Ridgway, Hellenistic Sculpture I. The Styles of ca. 331-299 B.C. Madison, WI, University of Wisconsin Press.

V. Scheibelreiter-Gail, Die Mosaiken Westkleinasiens. Tessellate des 2. Jahrhunderts v. Chr. bis Anfang des 7. Jahrhunderts n. Chr., Vienna, Österreichisches Archäologisches Institut.

C. Sintes - R. Ymouna, Algérie antique. Arles, Editions du musée de l'Arles et de la Provence antiques.

R. Talgam - Z. Weiss, The Mosaics of the House of Dionysos at Sepphoris, Jerusalem, The Hebrew University of Jerusalem.

M. Tarradell, Arte romana en Espana, Barcelona, Ediciones Poligrafa, S.A.

M. A. Valero Tévar, "The Late-Antique Villa at Noheda (Villar de Domingo García) near Cuenca and Its Mosaics", JRA 26,1, 307-330.

S. Vargas Vázquez, Diseños geometricos de los mosaicos de Écija (Sevilla), Oxford, Oxford University Press.

D. Von Bothmer, Amazons in Greek Art, Oxford, Oxford University Press.

S. Weinberg, Corinth I, pt. V, The Southeast Building, the Twin Basilicas, the Mosaic House, Princeton, Princeton University Press.

D. Willers, Der Dionysos-Behang der Abegg-Stiftung, Riggisberg, Abegg-Stiftung.

M. Yacoub, Le musée du Bardo, Tunis, Editions de l'Agence Nationale du Patrimoine.

M. Yacoub, Splendeurs des mosaïques de Tunisie, Editions de l’Agence Nationale du Patrimoine. 
